\title{
Paraguay: Recent Economic Developments
}

This Recent Economic Developments report on Paraguay was prepared by a staff team of the International Monetary Fund as background documentation for the periodic consultation with this member country. As such, the views expressed in this document are those of the staff team and do not necessarily reflect the views of the Government of Paraguay or the Executive Board of the IMF.

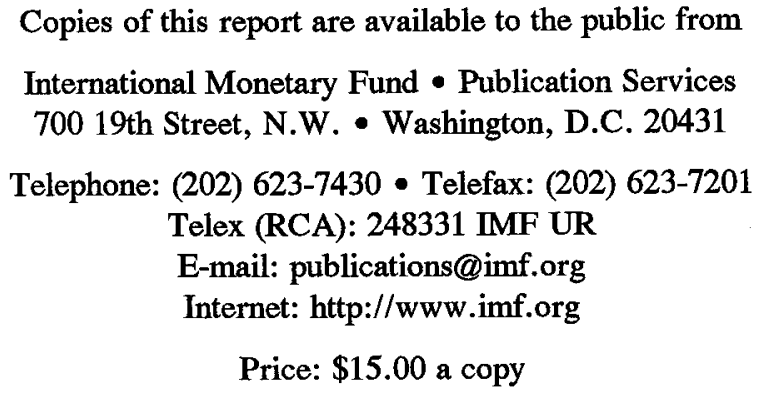




\section{INTERNATIONAL MONETARY FUND}

\section{PARAGUAY}

\section{Recent Economic Developments}

Prepared by J. M. Bailén, B. Braumann, and J. C. Jaramillo (all WHD)

Approved by the Western Hemisphere Department

December 22, 1998

Contents

Page

Basic Data 3

I. Output, Growth and Prices $\ldots \ldots \ldots \ldots \ldots \ldots \ldots \ldots \ldots \ldots \ldots \ldots \ldots \ldots \ldots \ldots \ldots \ldots \ldots \ldots$

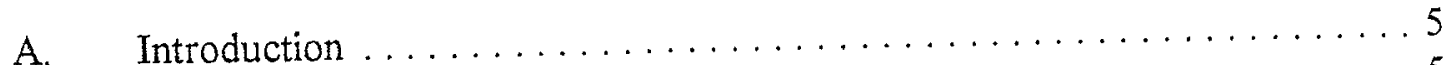

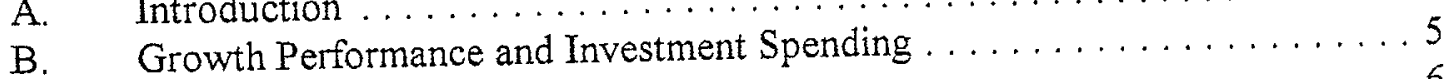

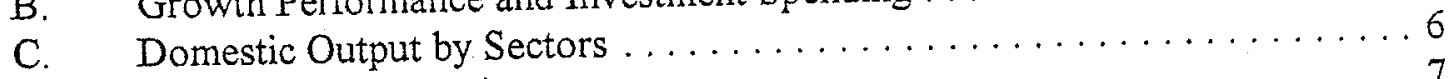

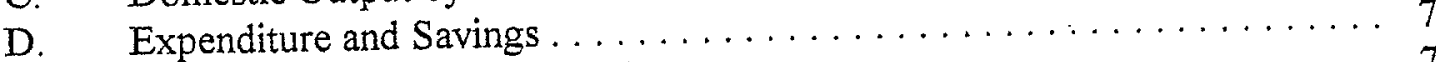

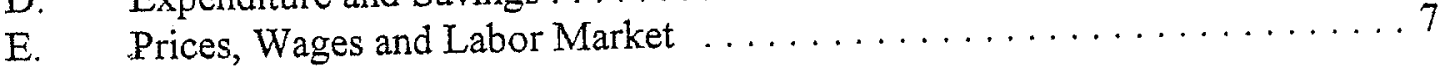

II. Public Finances $\ldots \ldots \ldots \ldots \ldots \ldots \ldots$

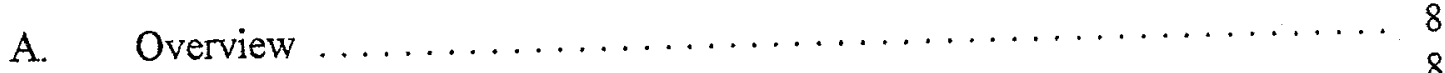

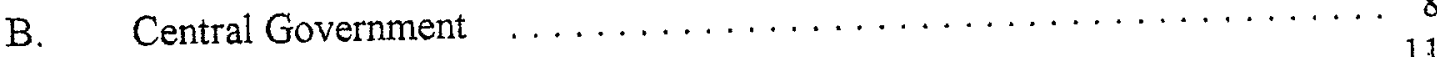

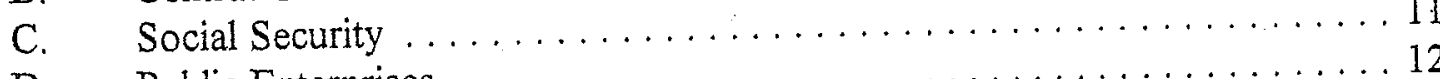

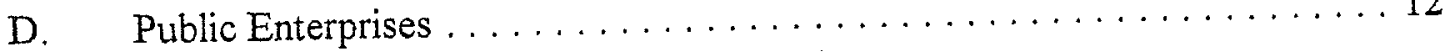

III. Monetary Developments and the Banking Sector $\ldots \ldots \ldots \ldots \ldots \ldots \ldots$

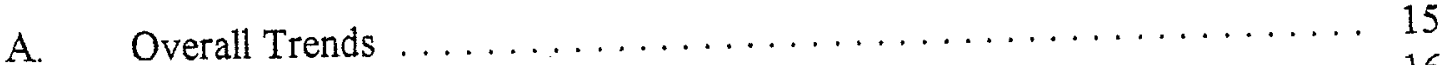

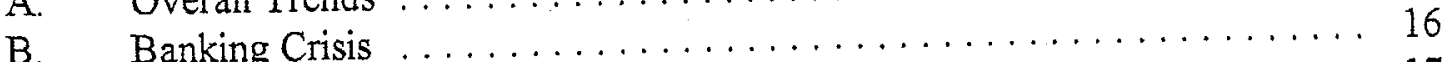
C. Indicators of the Extent of the Crisis . . . . . . . . . . . . . . 17

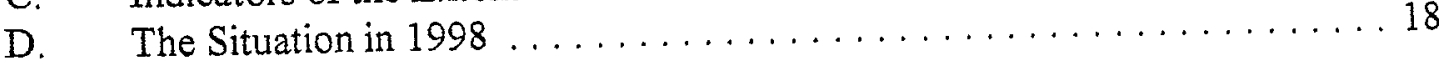


IV. External Sector .

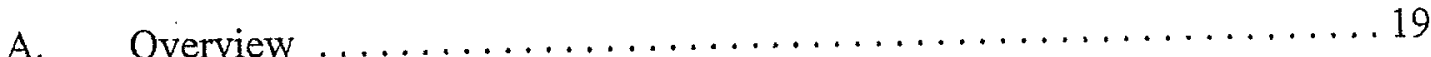

B. Balance of Payments Developments . . . . . . . . . . . . . . . . 19

C. The Exchange and Trade System $\ldots \ldots \ldots \ldots \ldots \ldots \ldots \ldots \ldots \ldots \ldots \ldots \ldots \ldots \ldots \ldots \ldots \ldots$

\section{Tables}

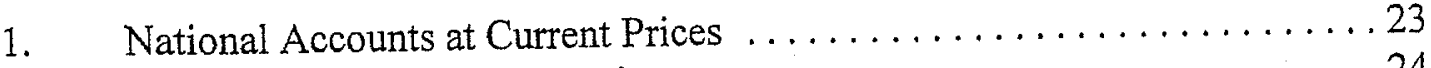

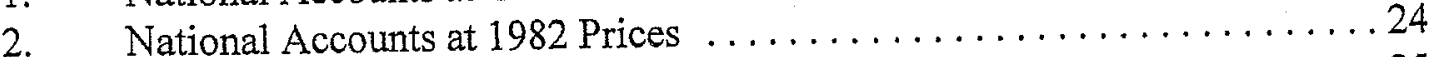

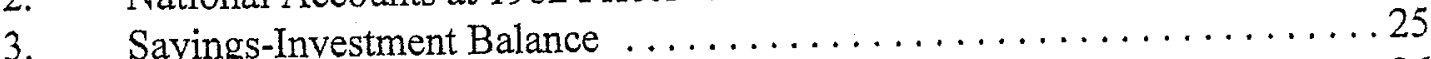

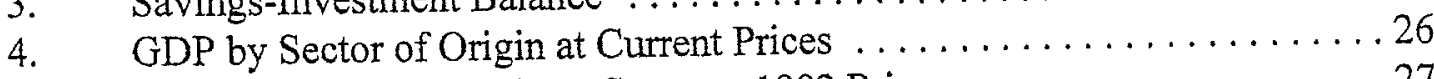

5. GDP by Sector of Origin at Constant 1982 Prices ............... 27

6. Volume of Agricultural Production .......................... 28

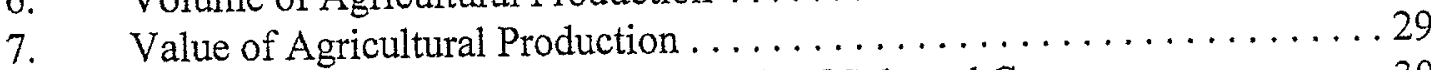

8. Production, Area Cultivated and Yields of Selected Crops ............ 30

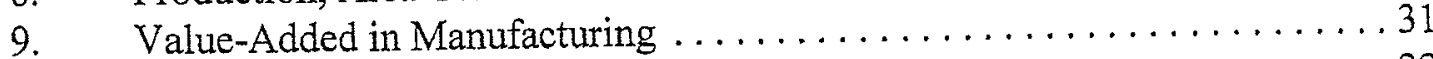

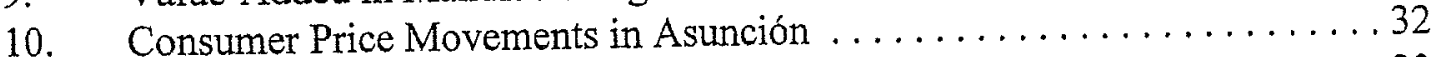

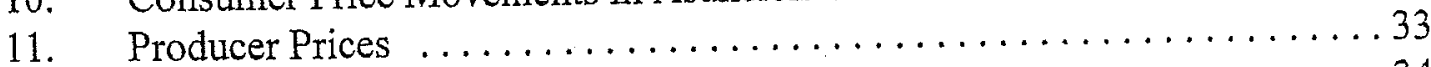

12. Labor Market Indicators ................................... 34

13. Operations of the Consolidated Public Sector .................. 35

14. Operations of the Central Government ...................... 36

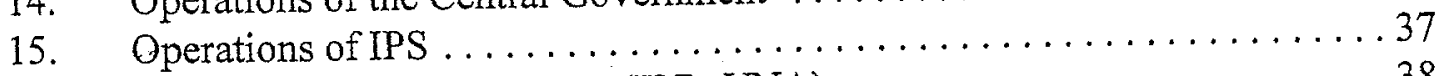

16. Rest of General Government (IBR, UNA) $\ldots \ldots \ldots \ldots \ldots \ldots \ldots \ldots \ldots \ldots$

17. Operations of the Public Enterprises . . . . . . . . . . . . . . . . . 39

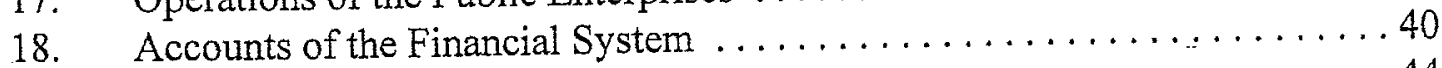

19. Costs of Banking Rescue Operations ...................... 44

20. Banking System - Distribution of Credit to the Private Sector ........ 45

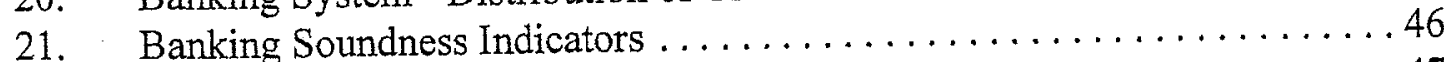

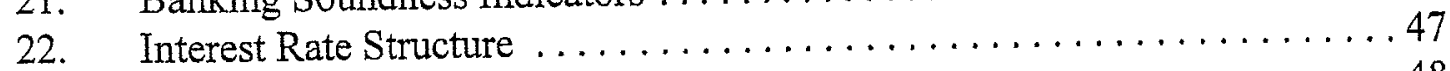

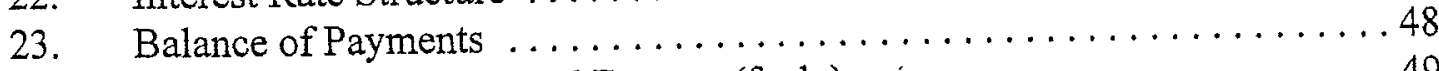

24. Composition of Registered Exports (f.o.b.) . . . . . . . . . . . . . 49

25. Composition of Registered Imports (f.o.b.) $\ldots \ldots \ldots \ldots \ldots \ldots \ldots \ldots \ldots$

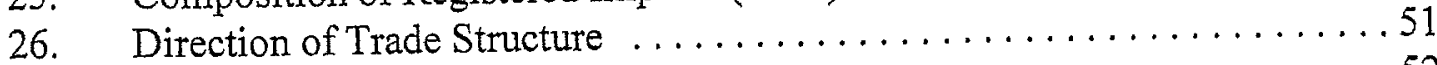

27. International Reserves of the Banking System $\ldots \ldots \ldots \ldots \ldots \ldots \ldots . \ldots \ldots$

28. Outstanding Medium- and Long-Term External Public Debt $\ldots \ldots \ldots \ldots 53$

\section{Figures}

1. Performance of Major Public Enterprises $\ldots \ldots \ldots \ldots \ldots \ldots \ldots \ldots \ldots$

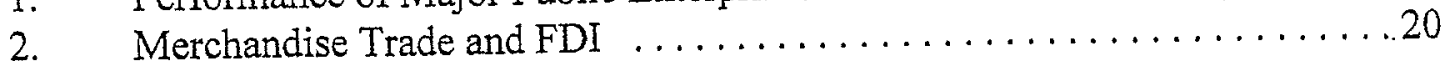




\section{Paraguay: Basic Data}

\section{Social and Demographic Indicators}

Area (thousand sq. km)

Population (1997)

Total (million)

Rate of increase (percent a year)

Density (per sq. km.)

GDP per capita (US\$) (1997)

Unemployment (Asuncion, 1996)

Population characteristics (1995)

Life expectancy at birth (years)

Crude birth rate (per thousand)

Crude death rate (per thousand)

Infant mortality (per thousand live births)

Income distribution (1995)

By highest 20 percent of households

By lowest 20 percent of households
$397,500 \mathrm{~km} 2$

5,05 million

2.9

12.7 per $\mathrm{km} 2$

US\$ $19551 /$

8.2 percent

40.6

52.0

46 percent

6 percent
Nutrition (1994)

Calorie intake

(per capita a day)

Health

Population per physician (1991) 1,231

Population per hosp. bed (1989) 762

Access to safe water (percent

of population, 1995)

Total

Urban

33

49

17

Education (in percent, 1995)

Adult literacy rate

92 percent

Primary school enrollment

II. Economic Indicators, 1994-98

\begin{tabular}{rrrrrrr}
\hline Est. \\
\hline
\end{tabular}

(In annual percent changes)

National accounts and prices

GDP at constant 1982 market prices

Agriculture and mining

Manufacturing

Commerce and finance

Consumer price index (end of period)

18.3

$\begin{array}{rr}3.1 & 4.7 \\ -3.0 & 11.4 \\ 1.5 & 3.0 \\ 4.3 & 1.6\end{array}$

1.3

2.6

4.9

$-0.2$

(In percent of GDP)

Gross investment

Private consumption

Public consumption

Gross national saving

23.4

70.7

8.6

22.6

(In billions of guaranies)

Public Sector finances

Revenue

2,624

1,887

3,677

Current expenditure

Capital expenditure

Current balance (deficit -)

Overall balance (deficit -)

Memorandum items:

Current balance (percent of GDP)

Overall balance (percent of GDP)

\section{Money}

Money

Quasi-money

Net domestic assets

Credit to the public sector

Credit to the private sector

\section{.}


Paraguay: Basic Data (Concluded)

\begin{tabular}{|c|c|c|c|c|c|}
\hline & & . & & & Proj. \\
\hline & 1994 & $19 \dot{95}$ & 1996 & 1997 & 1998 \\
\hline & (In millions & dollars) & & & \\
\hline Balance of payments & & & & & \\
\hline Trade balance & -182 & -262 & -379 & -446 & -276 \\
\hline Exports, f.o.b. & 3,422 & 4,231 & 4,004 & 3,768 & 3,384 \\
\hline Imports, f.o.b. & $-3,604$ & $-4,493$ & $-4,382$ & $-4,215$ & $-3,660$ \\
\hline Services and transfers (net) & 8 & -175 & -42 & .124 & -49 \\
\hline Current account & -56 & -364 & -317 & -483 & -265 \\
\hline Capital account & 286 & 523 & 191 & 573 & 166 \\
\hline Overall balance & 346 & 62 & -44 & -216 & -99 \\
\hline Memorandum items: & & & & & \\
\hline Current account (as percent of GDP) & -0.7 & 4.1 & -3.3 & -5.0 & -3.1 \\
\hline External debt outstanding (as percent of GDP) & 15.8 & 15.6 & 14.5 & 15.0 & 17.3 \\
\hline IMF data (as of November 30,1998 ) & & & & & \\
\hline Membership status & & & & & Article VIII \\
\hline Intervention currency and rate & & & & U.S. dolla & (G 2,804/dollar) \\
\hline Quota & & & & & SDR 72.1 million \\
\hline Fund holdings of local currency & & & & . & SDR 57.6 million \\
\hline Fund holdings as percent of quota & & & & & 79.9 \\
\hline Reserve position in the Fund & & & & & SDR 14.5 million \\
\hline As percent of quota & & & & & 20.2 \\
\hline Total Fund credit & & & & & None \\
\hline Special Drawing Rights Department & & & & & \\
\hline Cumulative SDR allocation & & & & & SDR 13.7 million \\
\hline Net acquisition or utilization $(-)$ of SDRs & & & & & SDR 61.7 million \\
\hline Holdings of SDRs & & & & & SDR 75.4 million \\
\hline
\end{tabular}

Sources: Paraguayan authorities; and Fund staff estimates. 


\section{Output, Growth ANd Prices}

\section{A. Introduction}

1. Paraguay's economy is heavily dependent on agriculture and trade activities, which together represented more than 50 percent of GDP in 1997 (Table 4). The share of these sectors in GDP has remained stable during the 1990's, although there has been a gradual decline in the importance of trade activities due to a reduction in reexport (entrepôt) trade after the implementation of Mercosur in 1995.

2. An important characteristic of the economy is the presence of a sizable informal sector, which is not recorded in official GDP figures. According to some estimates, the underground economy represents some 50 percent of total output. The importance of informal activities is attributed, in part, to the rigidity of the labor market, which imposes a minimum wage of about US $\$ 200$ per month (equivalent to 1.5 times monthly per capita GDP) as well as high dismissal costs. Another reason can be found in long-standing practices of informal trade and contraband with neighboring countries, due to differential taxation and the lack of strong border controls.

\section{B. Growth Performance and Investment Spending}

3. After recording a growth rate of 1.3 percent in 1996, real GDP expanded by 2.6 percent in 1997 , or about the same rate as population growth. This reflected mainly a recovery in agricultural output owing to abundant rains. GDP growth suffered a new setback in 1998 , with preliminary estimates showing a growth rate of only 0.6 percent, owing mainly to the continued stagnation in the manufacturing sector, a reduction of trade-related activities due to tighter border controls in Brazil, and the contractive effects of a lingering banking crisis on the economy.

4. Per capita GDP has been stagnant for nearly two decades, notwithstanding the fact that the country registers relatively high savings and investment rates, which currently exceed 20 percent of GDP. There are several factors which may explain Paraguay's high incremental capital output ratio (ICOR). First, the inclusion of the large informal sector in the GDP estimates would significantly lower the observed investment/output ratio, as the informal sector can be assumed to be less capital intensive than the rest of the economy. Second, the stock of human capital is low in Paraguay due to decades of underinvestment in education (education spending represented just 1 percent of GDP in the 1980's). The low education level of the population slows down the absorption of new technologies and productivity growth. Third, the stock of public infrastructure capital is insufficient, as documented by a ratio of public investment to GDP of only 2-3 percent during the 1980 s and the first half of the 1990s (Table 13). 


\section{Domestic Output by Sectors}

\section{Agriculture, livestock and forestry}

5. Agricultural output (plus livestock and forestry) represented 25 percent of GDP in 1997 , and the main crops are soybeans and cotton. The relative importance of soybeans has increased over the $1990 \mathrm{~s}$, helped by trends in international prices more favorable than for cotton. Cotton has also been adversely affected by abundant rains in 1997 (Table 8). The livestock sector accounts for about 8 percent of GDP and produces mostly beef; the output of forestry is mainly used in the domestic construction sector.

6. The paraguayan agricultural sector faces several problems. First, the small size of many farms (there are about 247,000 small farms) makes mechanization difficult. Second, the low educational level of most farmers represents a barrier to the adoption of new technologies. Third, there is a lack of diversification in agricultural production, which is highly concentrated in three or four main crops. The low diversification of the agricultural production increases the risk exposure of farmers. As a consequence of these problems, only soybeans-which is mainly produced on big, mechanized farms-and corn have registered significant gains in productivity in the last eight years.

\section{Manufacturing}

7. The manufacturing sector represents about 14 percent of GDP. A large share of industrial production is based on the processing of agricultural raw materials, which includes the foodstuff, beverage and timber industries, representing 63 percent of total industrial production. Other important industries are handicrafts, leather and hides, and textiles. Almost no consumer durables or capital goods are produced in Paraguay.

8. In 1997 , manufacturing output fell by 0.2 percent. Preliminary estimates show a modest growth of about 1 percent in 1998 . During the $1990 \mathrm{~s}$, manufacturing output was virtually stagnant in real terms, with its share in total output declining to 14 percent in 1997. The decline has been particularly severe in labor intensive industries, such as textiles, handicrafts, and shoes, as well as in domestic petroleum refining. The relatively high labor costs in Paraguay contributed to the weakness of labor intensive industries, whereas imports from more competitive refineries in neighboring countries led to a fall in output of the petroleum refining industries after the implementation of Mercosur in 1995.

\section{Services}

9. The share in total GDP of commerce and finance activities is roughly one third, and has been strongly influenced by the reexport activities. The mostly informal reexport trade reached a peak in 1995, as a large differential in taxation across the border combined with a consumption boom in Brazil. However, since then the lowering of tariff barriers in Mercosur, tighter border controls, and a cooling of the brazilian economy have contributed to a downturn in reexport activities, and correspondingly in the commerce sector. In addition, a 
protracted financial crisis has resulted in the closure of 13 domestic banks since 1995, representing about one third of deposits (see section III below). This has reinforced the downturn of the sector, whose share in GDP fell from a peak of 31 percent in 1995 to 27 percent in 1998.

\section{Expenditure and Savings}

10. During the mid-1990s, a surge in investment expenditures boosted domestic demand to growth rates that exceeded real GDP growth by an average of 2 percent per year. The result was a rapid deterioration of the external current account, which shifted from a surplus of almost 4 percent of GDP in 1993 to a deficit of 4 percent in 1995. The investment surge was initiated by a rapid expansion of private investment, followed a moderate pick up of public investment after 1995. Public capital spending had been constrained to unsustainably low levels during the first half of the 1990s, and there was a need to undertake long postponed maintenance investment in both the general government and public enterprises (see Section II below).

11. After 1995, the effects of the crisis in the financial system began to be felt in a marked slowdown of domestic demand. Investment expenditures began to decline in real terms in 1996, and the contraction accelerated markedly in 1998 with an estimated negative growth rate of -11 percent. A doubling in the ratio of public investment to GDP relative to the first half of the 1990s could not offset the sharp contraction of private investment. Funds for the financing of private projects virtually dried up, as banks became concerned with the risk structure of their loan portfolios and were reluctant to extend new loans. Accordingly, the share of private investment in GDP fell from 20 percent in 1994 to 14 percent in 1998.

12. The deceleration of total demand was more modest, as consumption expenditures grew faster than GDP and to some degree offset the decline in investment. As a result, the deficit in the external current account bottomed out at 5 percent of GDP in 1997, and narrowed to 3 percent in 1998. Consumption growth was concentrated in the public sector, following large wage increases for civil servants, which increased the ratio of public wage expenditures from 7 to 9 percent of GDP between 1994 and 1998 (Table 13).

\section{E. Prices, Wages and the Labor Market}

13. After peaking at around 45 percent in 1991, inflation (as measured by the consumer price index) generally followed a downward trend during the $1990 \mathrm{~s}$, dropping to 6.2 percent by end 1997. This was the result of a modest appreciation of the exchange rate, a tightening of monetary policy and a continued decline in food prices. However, after a depreciation of the guarani by about 30 percent on a year-to-year basis in the first months of 1998, inflation began to accelerate and reached 16 percent by October 1998 . Wholesale price inflation has been higher than CPI inflation because of the larger weight of tradeable goods in its index.

14. Real minimum wages, which had declined by more than 20 percent during the early 1990 s, recovered by almost 15 percent since 1994, with the largest increase (5.2 percent) in 
1997. Average real wages in the economy have also increased by around 15 percent since 1994, although in general their evolution is not closely linked to the minimum wage. In Paraguay, the average wage (about US\$195 per month) is lower than the minimum wage, because of the presence of the large informal sector. Indeed, according to government sources, about 80 percent of paraguayan workers receive wages lower than the official minimum wages.

15. The relatively high minimum wage, as well as other labor market rigidities, is one of the main factors giving rise to the underground economy. Although minimum wages are not actually binding in rural areas and for small enterprises operating in the informal sector, they represent an important rigidity to medium and large enterprises, and to foreign investment.

\section{Public Finances}

\section{A. Overview}

16. Paraguay maintained a generally conservative fiscal policy stance during the past ten years. The government that assumed power in 1989 implemented a comprehensive fiscal adjustment program which included tax increases, cuts in capital spending and a significant turnaround in the finances of public enterprises. As a result, the balance of the public sector shifted from a deficit in excess of 3 percent of GDP in 1988 to a surplus of almost 5 percent of GDP in 1991. This achievement was partially eroded in subsequent years, as tax collection weakened and public employees received generous wage increases. The deterioration became particularly marked after 1995, and by 1997 the overall balance slid into a deficit of around 1 percent of GDP, reflecting mainly the strong growth of wages and transfers.

17. Because of the public sector surpluses during the 1990s, Paraguay was able to reduce its external debt (there is no significant internal debt). From a peak of US $\$ 2.1$ billion at the end of 1989 (51 percent of GDP), the public sector's medium and long-term external debt fell to US\$1.4 billion (15 percent of GDP) at the end of 1997. This included the clearing of arrears to Paris club members in 1992. Debt service obligations amount to less than 4 percent of exports of goods and services in 1997.

\section{B. Central Government}

18. The position of the central government finances weakened in recent years. The overall balance shifted from an average surplus of 1 percent of GDP during 1989-93 to an average deficit of about 1 percent of GDP during the following five years. Government savings remained roughly unchanged at an average of 3 percent of GDP during both periods, as a strong increase in current expenditures (mainly wages and public pensions) was offset by higher revenues. However, capital spending also increased, to reconstruct the rapidly deteriorating public infrastructure that resulted from the low levels of public investment in the early 1990 s. 
19. At somewhat less than 12 percent, the ratio of tax revenues to GDP is among the lowest in the region. There is no personal income tax, and the VAT rate is 10 percent. Social security and other taxes on labor amount to 25 percent, but are widely evaded. The corporate income tax rate is 30 percent, but is reduced to 10 percent if profits are reinvested. The tax system is skewed towards indirect taxes, which account for three quarters of all tax revenues. This bias has helped reduce fluctuations in government revenues as the tax base reflects mostly consumption. However, due to its lack of a personal income tax, the tax system performs poorly as an automatic stabilizer and does little to make income distribution more equitable.

20. Notwithstanding, the low level of taxation, over the last ten years tax revenues had increased as a percentage of GDP, from 7.4 percent in 1988 to more than 12 percent in 1995, leveling off thereafter. Initially, receipts from trade taxes (customs duties) expanded after a temporary levy was introduced on exports in 1989 and the exchange rate unification ended a preferential treatment of imports. The substitution in 1992 of the VAT for several stamp taxes and a cascading sales tax was designed to be revenue-neutral and had no immediate effects. Over time, however, the change yielded fiscal benefits, increasing the ratio of taxes on goods and services to GDP by a full percentage point between 1993 and 1997. The increased demand in Brazil, following the introduction of the real in 1994, resulted in an expansion of border trade and boosted trade tax revenues in Paraguay. Improvements in tax administration also contributed to enhance the collection of corporate income taxes and the VAT.

21. From 1996 to mid-1998, tax revenues slipped as a percentage of GDP. A cooling brazilian economy and stricter border controls reduced reexport trade and receipts from trade taxes. In addition, declining economic activity in Paraguay and slackening collection efforts diminished revenues from the corporate income tax. Numerous nontransparent exemptions from this tax and a relatively high core rate of 30 percent are frequently blamed for encouraging evasion and informal activities.

22. To help restore the fiscal balance, the administration that assumed office in August 1998 has cut the list of exemptions from the VAT and import tariffs (goods classified as "tourist items"), and increased excise taxes on fuel, alcohol and cigarettes. In addition, a campaign of on-site controls in businesses has led to an increase in the collection of VAT and corporate income taxes during the last months of 1998.

23. Paraguay continues to enjoy a number of exemptions from the common external tariff of Mercosur. Capital goods, production inputs and cars are taxed at lower rates, as is a long list of consumer goods that qualify for "tourist trade". A sizeable sector of the economy is taking advantage of the tariff differentials and engages in entrepôt trade, mainly with Brazil. However, these profit opportunities are bound to disappear as the exemptions are phased out by the end of 2005 .

24. Royalties from the Itaipú binational hydroelectric company have been an important source of nontax revenue for the government since the dam began operating at capacity in 
1990. The payments are based on the sale of electricity to Brazil and have averaged 2.3 percent of GDP during the 1990s. Electricity production is influenced by climatic conditions and the water volume of the river Parana. A drought reduced royalties to 1.9 percent of GDP in 1996, whereas wet conditions associated with El Niño boosted them to 2.8 percent in 1998.

25. Starting from low levels, current expenditures have more than doubled over the last decade, from 6.4 percent of GDP in 1988 to 13.4 percent in 1998. This is mostly attributed to a surge in wages and transfers, both of which have trebled in relation to GDP over this period. At the end of the Stroessner administration in 1989, the government payroll had been compressed to just 2.4 percent of GDP, giving rise to an inefficient civil service and widespread corruption. To redress this situation, the subsequent administrations granted civil servants sweeping increases in wages, raising their share to an estimated 7.6 percent of GDP by 1998 . Special attention was given to the salaries of teachers, health professionals, and military and police personnel. Parallel to the political liberalization, unionism started to take hold in the public sector, accelerating the pace of wage increases in 1996 and especially in 1997. In addition to Law 200 of 1973, which makes dismissals difficult and costly, the assertive stance of unions has reinforced the rigidities in public employment.

26. Being indexed to public sector wages, government pensions have also trebled since 1988 in relation to GDP. Indexation together with abuses in the collection of benefits have opened a financing gap of close to 1 percent of GDP in the government's pension fund. General tax revenues are used to fill this gap, financing more than half of the state pension system. Interest expenditures reached a peak in 1992, before Paraguay settled its arrears with a one-time payment to members of the Paris Club. After that, interest expenditures dropped to an average of 0.6 percent of GDP, reflecting consecutive years of fiscal surpluses and the reduced size of the public sector debt.

27. Shortly after taking power in August 1998, the government of president Cubas enacted Decree No. 6, designed to curtail current expenditures. The decree reduced paid overtime and specified lists of cuts in consumption of goods and services for all entities of the public sector.

28. Government investment expenditures were maintained at an average of only 1.9 percent of GDP between 1989 and 1993. Maintenance investment was postponed, allowing public infrastructure to deteriorate. The situation improved somewhat after 1992, when Paraguay reached an agreement with foreign lenders over its arrears and external funds returned to the country. In an effort to provide counterpart project financing, the Wasmosy administration doubled capital spending to an average of 4 percent of GDP over the years 1994-98. However, compared to other countries in the region, Paraguay lags substantially behind in basic infrastructure areas, such as access to safe water, sanitation and telephone services. 


\section{Social Security}

29. In Paraguay, basic social security is provided by 6 different institutions. The largest is the Instituto de Prevision Social (IPS), which covers private sector employees, or about 52 percent of all contributors. Second with a share of 44 percent is the Caja Fiscal, covering most public sector employees. Finally, four smaller Cajas cover the remaining employees of banks, railways, municipalities and the legislative branch.

30. The fragmentation and regulatory complexity of the pension system has been a source of inefficiencies and a major obstacle to reform. IPS bears a special burden, since it is designed to provide health care in addition to old age pensions. Unlike the public sector Cajas, however, IPS consistently ran operational surpluses over the last decade. ${ }^{1}$ This is mainly due to the youth of the system, and a correspondingly high ratio of 8 contributors per beneficiary. The contributions are financed from a 23 percent payroll tax, of which 12.5 percent go to pensions, 9 percent to health care and 1.5 percent to administrative expenses. For the time being, most of the expenditures are related to health care, and not to pensions. Because pension benefits are tied to an average of past salaries and there is no adequate mechanism of indexation, they are progressively eroded by inflation. As a result, 94 percent of pension payments fall below the minimum wage. ${ }^{2}$ In addition, IPS's coverage reaches only 40 percent of Paraguay's nonfarm private employees, with the rest receiving neither health care nor pension benefits.

31. All social security institutions in Paraguay operate on a pay-as-you-go basis. Despite recording operational surpluses at the moment, IPS is estimated to be in actuarial deficit, and so are all other social security institutions. ${ }^{3}$ The situation might deteriorate even faster than expected because of a misguided investment strategy of IPS. Until 1992, the accumulated surpluses were held in accounts at the Central Bank, which paid no interest. Since then, IPS shifted its assets into interest-bearing deposits at domestic private banks, which helped its surplus to double from 0.5 to 1 percent of GDP. However, of the roughly 1.1 billion guaranies of IPS's total assets (5 percent of GDP), more than half were invested in banks which later became insolvent and had their operations suspended. In 1997 and 1998, IPS acquired shares of Banco Desarrollo in a failed attempt to avoid the closure of that bank. The shares were lost in September 1998, as Banco Desarrollo was declared insolvent. In addition, IPS made a number of unredeemable loans to private firms.

${ }^{-1}$ The financial position of the Caja Fiscal and the smaller public pension schemes is shown in Table 14. That of IPS can be seen separately in Table 15.

${ }^{2}$ World Bank Country Economic Memorandum 18392-PA, p.37. However, the minimum wage in Paraguay is higher than GDP per capita (see section I.E).

${ }^{3}$ Cruz-Saco, A. (1994): "Instituto de Previsión Social del Paraguay (IPS): Diagnóstico Económico, Financiero y Alternativas de Reforma." An actuarial deficit means that the present value of future operational balances is negative. 


\section{Public Enterprises}

32. Paraguay currently has eight fully state-owned enterprises, most of which are utilities that operate in a monopolistic market setting. The three largest enterprises, which account for 82 percent of total expenditures, are ANDE (distribution of electricity), PETROPAR (gasoline and diesel) and ANTELCO (telecommunications). Furthermore, there are two medium-sized companies, CORPOSANA (water and sewerage) and INC (cement) and three small ones (the administrations of river ports, of airports, and an antiquated wood-burning railroad).

33. The most visible success of the fiscal adjustment during the late 1980 s was a drastic turnaround in the finances of public enterprises. Cuts in investment and improvements in the operational balances of the public enterprises transformed an overall deficit of 3.5 percent of GDP in 1988 into a surplus of 1.7 percent in 1991. Tariffs were sharply increased, and current expenditures were cut from 10.3 percent of GDP in 1988 to 7.6 percent in 1991 by rationalizing operations and reducing staff. Investment expenditures dropped by more than 75 percent in real terms between 1988 and 1991, as some large projects were completed and capacity expansion was postponed for lack of foreign financing. During most of the $1990 \mathrm{~s}$, the public enterprises maintained overall surpluses, which reached a peak in 1995 after a second round of tariff increases.

34. More recently, public enterprises slid back into deficit, contributing to the deterioration of the overall public sector balance. The low level of investment during the first half of the 1990s resulted in capacity bottlenecks and in a general deterioration of the capital stock, a situation that gradually became unsustainable. Since 1996, investment expenditures have more than doubled in real terms, although the quality of infrastructure remains far from satisfactory, especially in the provision of electricity and water. Tariffs of public enterprises are set by the government once a year, in principle so as to ensure an average return on capital of around 8 percent. However, regulatory lags have built up for many companies, especially for ANTELCO where tariffs have been frozen since 1994. This, together with an expanding wage bill in a strongly unionized setting, has led to a compression of operational balances. Figure 1 shows the evolution of key financial variables for the four largest enterprises.

35. The depreciation of the guarani by around 30 percent in early 1998 exposed the vulnerability of some large public enterprises, such as ANDE and PETROPAR, to exchange rate fluctuations. Their operating expenditures are almost exclusively in U.S. dollars, while tariff revenues are collected in guaranies. In addition, most of the enterprises' recently stepped-up investment expenditures are in foreign exchange.

36. Since the law allowing privatizations was approved in 1991, only one company has been sold, but without major fiscal benefits. The former national airline (LAPSA) was sold to 


\section{Figure 1. Performance of Major Public Enterprises}

ANDE

in constant 1992 prices

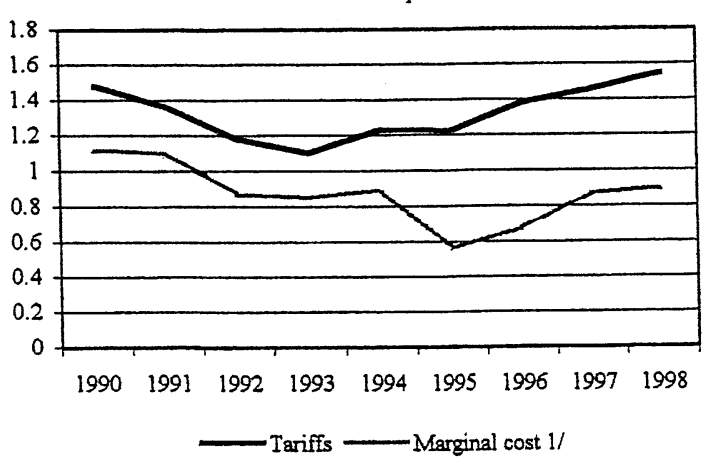

ANDE

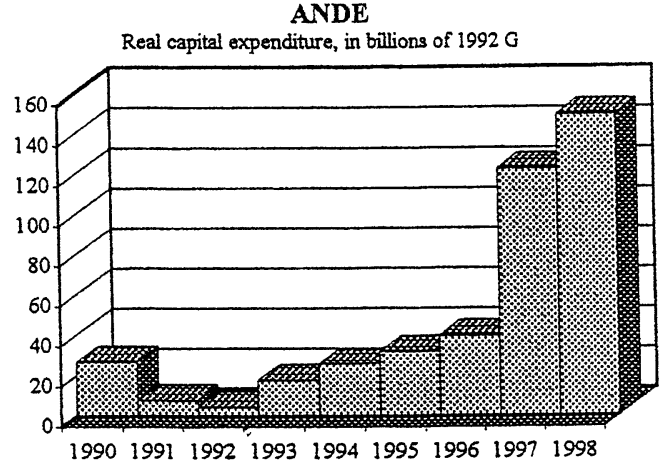

ANDE

Real profits in billions of $1992 \mathrm{G}$

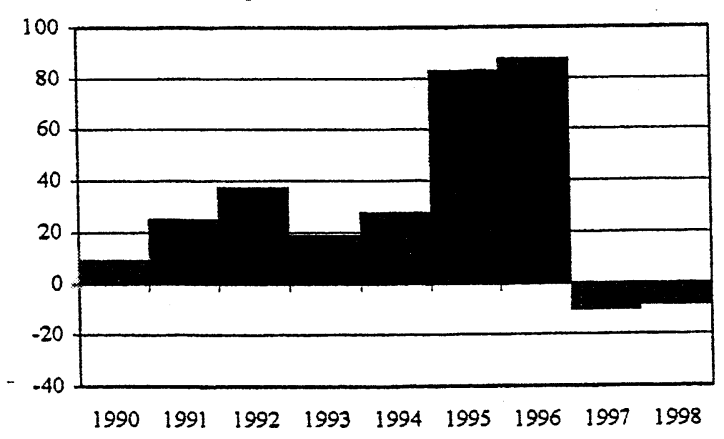

Corposana

in constant 1992 prices

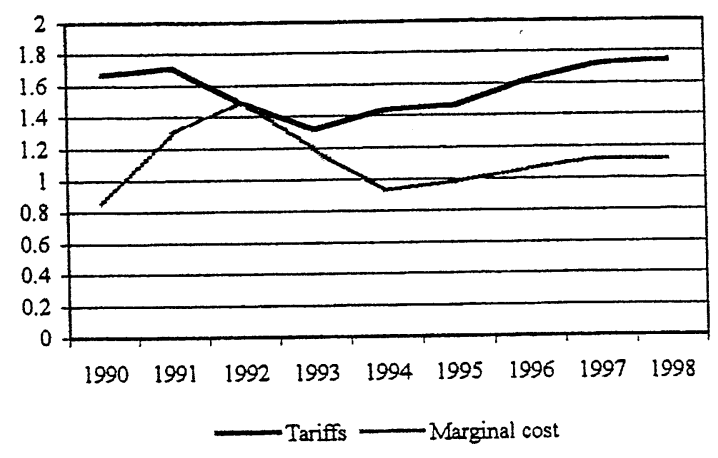

Corposana

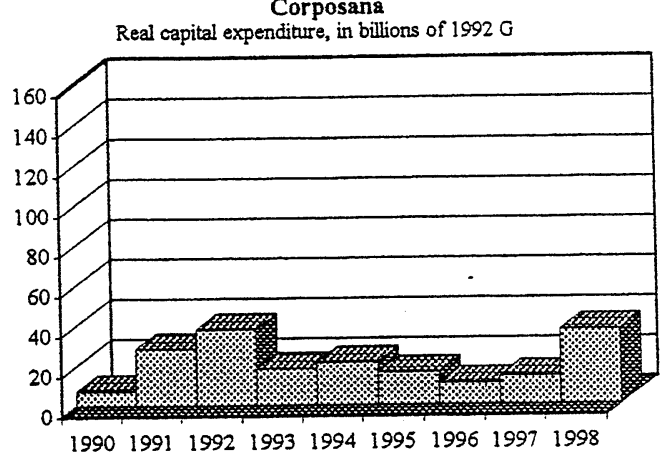

Corposana

Real profits in billions of $1992 \mathrm{G}$

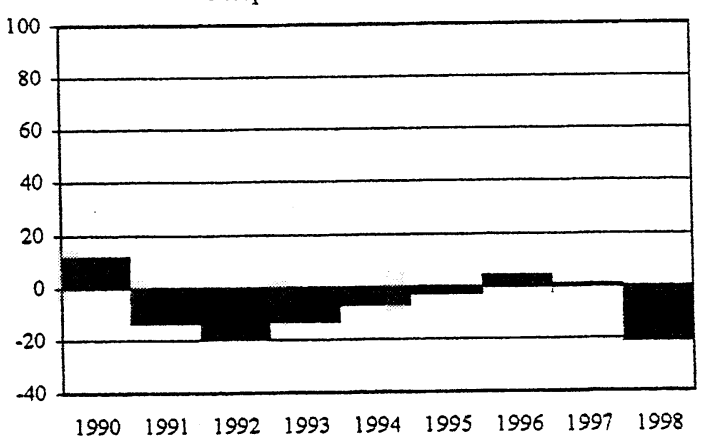

1/ Marginal costs are approximated as total variable cost (current expenditure) divided by output. 


\section{Figure 1. Performance of Major Public Enterprises (continued)}

ANTELCO

in constant 1992 prices

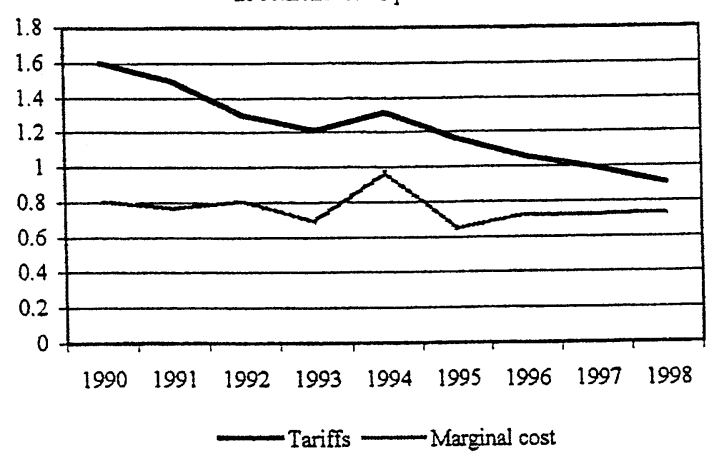

ANTELCO

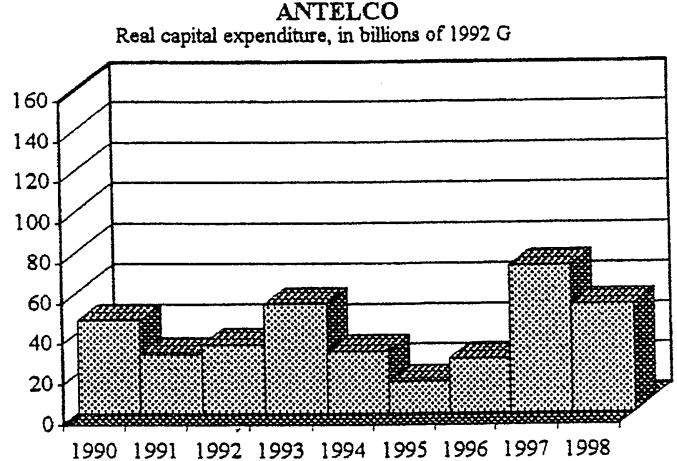

ANTELCO

Real profits in billions of $1992 \mathrm{G}$

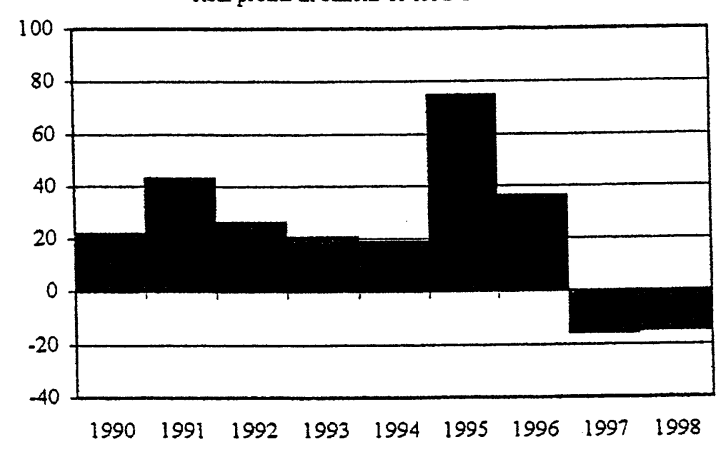

PETROPAR

in constant 1992 prices

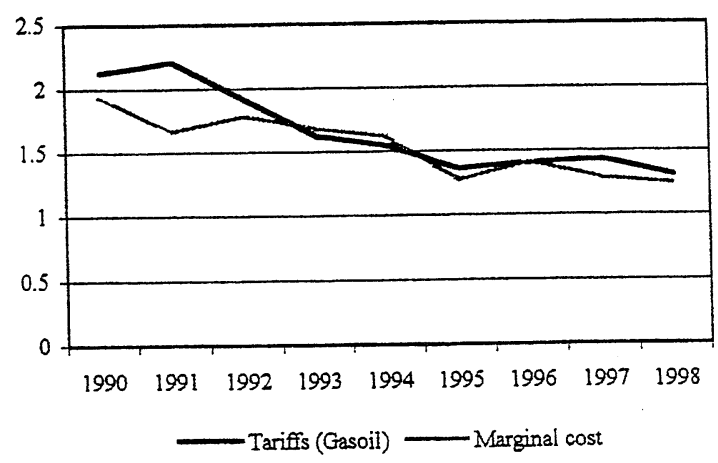

PETROPAR

Real capital expenditure, in billions of $1992 \mathrm{G}$

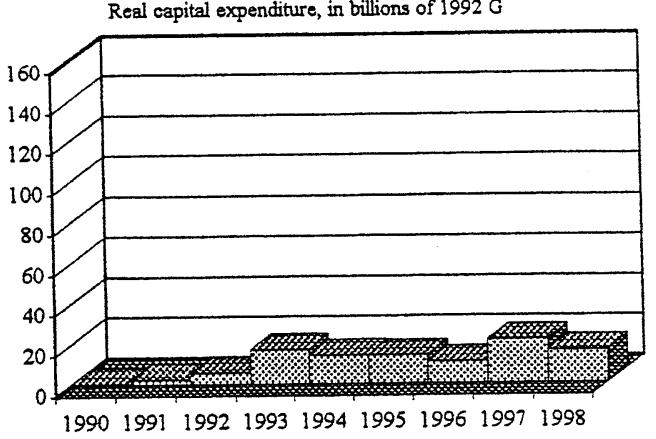

PETROPAR

Real profits, in billions of $1992 \mathrm{G}$

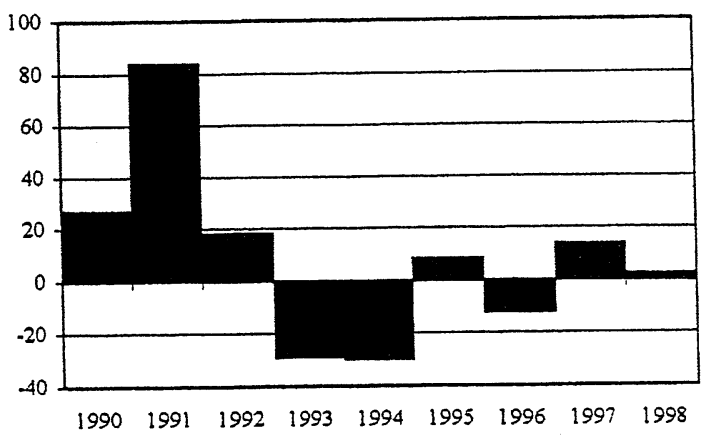


foreign investors, but the government absorbed more than US\$40 million worth of the company's liabilities, compared with its eventual sale price of US $\$ 23$ million. ${ }^{4}$ A principal obstacle to further privatizations is strong political opposition in congress and Article 111 in the 1992 constitution, which makes it difficult to sell a company to parties other than its own workers or suppliers.

\section{Monetary Developments and the BankIng Sector}

\section{A. Overall Trends}

37. During the early 1990s, a series of reforms were implemented in Paraguay's financial sector to improve resource allocation and allow financial transactions better to reflect market conditions. The exchange rate was unified, interest rates were freed, selective credit controls were eliminated, and restrictions on foreign currency denominated local loans were gradually eased. As a result, financial intermediation grew rapidly with broad money increasing from 22.5 percent of GDP in 1990 to 31.4 percent of GDP in 1995.

38. Consistent with a more market oriented conduct of monetary policy, the Paraguayan Central Bank (BCP) shifted from the use of reserve requirements to the placement of its own short term paper, at market determined interest rates, as a tool of short term liquidity management. Thus, reserve requirements on local currency deposits began to be partially remunerated and were reduced in steps, from 30 percent in 1993 to 18 percent currently. Requirements on foreign currency denominated deposits were initially unified and reduced in tandem with these on local currency deposits, but were subsequently raised again in an attempt to influence the composition of deposits offered by financial institutions.

39. As part of the financial sector reform process, and seeking to enhance competition within a sector that had been restricted and over-regulated for many years, the authorities eased minimum capital and other requirements for entry into the system. The growth of financial resource intermediation fostered by the reforms and the easing of entry into the financial sector resulted in the creation of a large number of banks and finance companies between 1990 and 1994. Although some institutions that previously operated in the informal lending markets were among the new entrants, many were entirely new operations. The large number of participants in a small-even if rapidly growing-market, limited the scope of achievable economies of scale and stretched the limited resources of the Banking Superintendency. Rapid growth of intermediaries also put pressure on the limited availability of human resources with expertise in modern banking.

40. Developments in the public finances were also conducive to vigorous financial sector growth, in particular from 1993 to 1996. During those years the fiscal surplus of the overall public sector averaged slightly over 1.6 percent of GDP per year, giving rise to a sizeable

\footnotetext{
${ }^{4}$ See Paraguay - Selected Issues and Statistical Annex SM/97/229, Sept. 3, 1997.
} 
build-up of deposits in the banking system. As a result, net credit from the banking system to

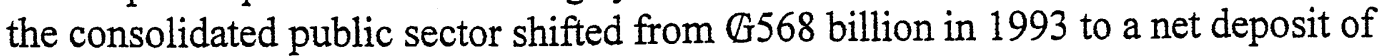
G498 billion in 1996, a turnaround equivalent to about 7 percent of GDP, providing ample resources for the expansion of the financial system. Credit to the private sector expanded at an average rate of 19.2 percent in real terms between 1990 and 1995.

41. During this period nominal interest rates declined, reflecting two reinforcing elements. The first was the ample flow of resources made available as the public sector became a net supplier of funds. The second was the gradual reduction of inflation. Rates on commercial credits declined from about 32 percent in 1993 to 25.6 percent by end-1997, while those on six-month certificates of deposit fell from 26 to 14 percent during the same period. Rates on the central bank's short term paper-letras de regulación monetaria (LRMs)-declined from 21.9 percent in 1993 to 12.1 percent.

\section{B. The Banking Crisis}

42. Difficulties in the financial sector began to surface already in late 1994. Several local banks, citing liquidity problems, sought and obtained central bank financial support. Their problems turned out to be far more severe than initially assessed and in 1995, when they failed to meet their financial obligations, four of these banks and several small finance houses ("financieras") were intervened by the Banking Superintendency. The intervened institutions held about 12 percent of the system's deposit base.

43. All intervened institutions were locally owned, as were several others whose liquidity problems surfaced during this first episode. Many depositors, in a "flight to quality", transferred their liquid holdings to foreign owned banks. To avert further runs against the local banks and a possible breakdown of the payments system, the central bank provided massive liquidity assistance to the ailing institutions, resources that largely served to pay-off most depositors and external creditors. Despite this, the affected intermediaries had to be liquidated eventually at a substantial economic cost (see section $\mathrm{C}$ below). As private depositors' preferences for foreign owned banks did not subside, several public enterprises and institutions supported local banks by moving their deposits to locally owned banks. This decision would later compound the public sector's losses attributable to the crisis.

44. The bank failures were caused by several factors, including poor supervision and regulation, excessive risk taking, loans to related enterprises and, in some cases, outright fraud. Moreover, as the first round of interventions did not fully address these problems, the system was left vulnerable to future shocks. Although there were shortcomings in the existing legislation, what lacked most was the adequate implementation of existing regulations. ${ }^{5}$ Given that the most basic problems of the banking system were only slowly addressed, while weak-and even insolvent-institutions were allowed to continue to operate through regulatory forbearance, the emergence of further difficulties was only a matter of time. The

${ }^{5}$ See SM/97/229, pp. 7-8. 
central bank continued to offer special liquidity support to financial institutions through various mechanisms during 1996 and 1997 ("Red de Seguridad" and "Préstamos de Rehabilitación"), but in mid 1997 a second wave of bank failures materialized, forcing the Banking Superintendency to intervene (and eventually liquidate) the largest local bank and the largest savings and loan company. Clients again shifted their deposits towards foreign owned banks, and the central bank, once again, provided liquidity assistance to locally owned banks. Problems were compounded by rumors about the nationalization of foreign currency deposits, which prompted depositors to seek safe havens abroad.

45. By 1997 the overall macroeconomic conditions were changing markedly. Particularly, the public sector's overall financial position had deteriorated, and from a surplus equivalent to 1.6 percent of GDP in 1996, it had shifted to a deficit of 1.1 percent of GDP in 1997. The financial counterpart of this change was a net increase of $\mathbb{G} 419$ billion in the public sector's use of resources from the banking system (Table 18). From a large net provider of funds, the public sector rapidly became a major user of funds. Interest rates on central bank paper reflected the change, increasing from below 10 percent at the end of 1996 to almost 30 percent in early 1998 . International reserves declined and the exchange rate depreciated, increasing the attractiveness of foreign currency deposits which by mid 1998 had risen to 48 percent of total deposits.

46. The adverse macroeconomic developments further stressed the financial stability of the remaining local banks. As a result, in the course of the first nine months of 1998 several other banks were intervened by the Superintendency, including Banco Nacional de los Trabajadores, a large public bank that included in its capital base compulsory contributions made by wage-earners over the years.

\section{Indicators of the Extent of the Crisis}

47. Table 19 provides information regarding the extent of the financial crisis. In nominal guaranies, the amount of nonperforming loans increased more than ten-fold since 1992 . In contrast, consumer prices over the same period did so by a factor of 1.8 , and credit to the private sector by a factor of 3.4. Furthermore, although capital and reserves increased from G300 billion to $\mathbb{G} 1.1$ trillion during this period, nonperforming loans by end-1997 represented 61 percent of the system's capital base (versus 22 percent in 1992) and 13.3 percent of total credit to the private sector.

48. From another perspective, the extent of the crisis may be gauged by examining the size of central bank support to the financial system (Table 18). Credit to banks and other intermediaries increased from $\mathbb{G} 187$ billion in 1992 to $\mathbb{G} 1.4$ trillion by end-1997. Although part of this increase is the result of normal operations between the central bank and financial intermediaries, most of the increase is associated with support to ailing banks. The increase in the credit to banks was equivalent to approximately 20 percent of the total credit outstanding to the private sector at the end of 1997. 
49. An upward limit to the quasi-fiscal costs of the crisis can be derived from Table 19 . The total accumulated cost since 1995 could reach $G 2.9$ trillion (US\$1.1 billion at today's exchange rate), or around 12 percent of GDP. The end result will depend on the size of the coverage that deposit insurance will provide to depositors - this is currently being debated in Congress, with a likely outcome of a maximum of 100 minimum wages (approximately US $\$ 20,000$ ) per account - and on the extent to which assets of the liquidated banks can be recovered. In addition, the central bank incurs losses estimated at some $\mathbb{G 1 2 0}$ billion (US\$40 million) per year on account of the sterilization of the liquidity increases stemming from the assistance to ailing banks and the monetization of the public deficit.

\section{The Situation in 1998}

50. The growth in monetary aggregates has decelerated. By end-September, adjusted ${ }^{6}$ broad money (a measure of both local and domestic currency deposits) was growing at an annual rate of 20 percent, down from 26 percent in September 1997. The decline, however, was not evenly distributed among different monetary aggregates. Foreign currency denominated deposits were moving up briskly, at an annual rate of 54 percent, while those denominated in local currency declined by 4 percent. The growth rate of guarani cash holdings had declined to 12 percent, from 20 percent a year earlier. To some extent, the banking crisis has affected the demand for monetary aggregates within Paraguay inducing depositors to hold a larger share of their assets in safer markets abroad, as evidenced by the decline of BCP's international reserves during the year. However, other forces have also played a role: first, as in other countries in the region, the effects of the Asia crisis has induced capital outflows and a decline in the demand for local monies; second, the low level of economic activity has taken its toll on the growth rate of currency and demand deposits; third, the depreciation of the guarani since end-1997 made foreign currency denominated deposits relatively more attractive; fourth, the expectations generated by the steady loss of reserves at the central bank during 1998 and by rumors of nationalization of deposits increased the demand for deposits abroad.

51. Interest rates increased over the first three quarters of 1998 partly reflecting an increase of inflationary expectations, but also as a deliberate policy response by the authorities to stabilize the foreign exchange markets. During the first half of 1997, interest rates on the central bank's LRM's had been held at about 11 percent. During the second half of the year they started to rise and reached 15 percent in December, and kept rising until May, when they surpassed the 30 percent level. Since then, they have come down sightly to about $27-28$ percent at the end of the third quarter.

52. By end-September 1998, after the Banking Superintendency intervened the last group of ailing institutions, there were 23 banks still operating in Paraguay. Of these, Banco Nacional the Fomento, was the only remaining publicly owned bank, with a market share of

${ }^{6}$ Broad money adjusted to eliminate measurement problems created by the freezing of deposits in intervened banks. 
about 11 percent. ${ }^{7}$ Another five institutions, holding approximately 9 percent of deposits, were locally owned by the private sector. Nine branches of foreign financial institutions held a market share of 49 percent, while banks with majority foreign capital held the remaining market share, 31 percent.

\section{EXTERNAL SECTOR}

\section{A. Overview}

53. The current account of the balance of payments showed increasing deficits during the 1990s, which reached the equivalent of 5 percent of GDP in 1997 (Table 23). The deficit narrowed to 3 percent in 1998, mainly due to a sharp decline in imports, reflecting the slowdown in economic activity.

54. Difficulties in the financial system since 1995, and the resulting loss of confidence in the paraguayan economy resulted in substantial capital outflow and loss of reserves. Net international reserves dropped from almost US $\$ 1.2$ billion in mid-1996 to around US $\$ 700$ million (or two months of imports) in October 1998. In December 1997, the central bank temporarily ceased to intervene in the foreign exchange market and let the guaraní depreciated by about 20 percent against the U.S. dollar in the following months. Since April 1998 , the exchange rate has been kept relatively stable.

\section{B. Balance of Payments Developments}

\section{Merchandise trade}

55. From a surplus position in the early 1990s, Paraguay's trade balance shifted into small deficits after 1994. Given that this development took place in circumstances where the main trading partners were growing at a faster rate than Paraguay, it reflects a structural weakening of the country's competitive position and an increasing deterioration of the fiscal balance. In 1998 , a contraction of domestic demand in the wake of a banking crisis led to a temporary reduction in the trade deficit:

56. Paraguay has traditionally followed an open trade policy. This has kept price distortions low, but also favored the emergence of a large sector based on reexport trade and contraband to higher-tariff neighboring countries. Figure 2 compares the magnitudes of reexports and trade for domestic use. Reexports increased sharply during the mid-1990s, fueled by tariff differentials and a surge in brazilian consumption following the real stabilization plan in 1994. By 1995, reexports reached 33 percent of GDP. The insertion of

${ }^{7}$ Market share here refers to percent of total banking system deposits. Shares when calculated as a percentage of total assets or loans do not differ much from those based on deposits. 
Figure 2.

\section{Merchandise Trade}

in percent of GDP
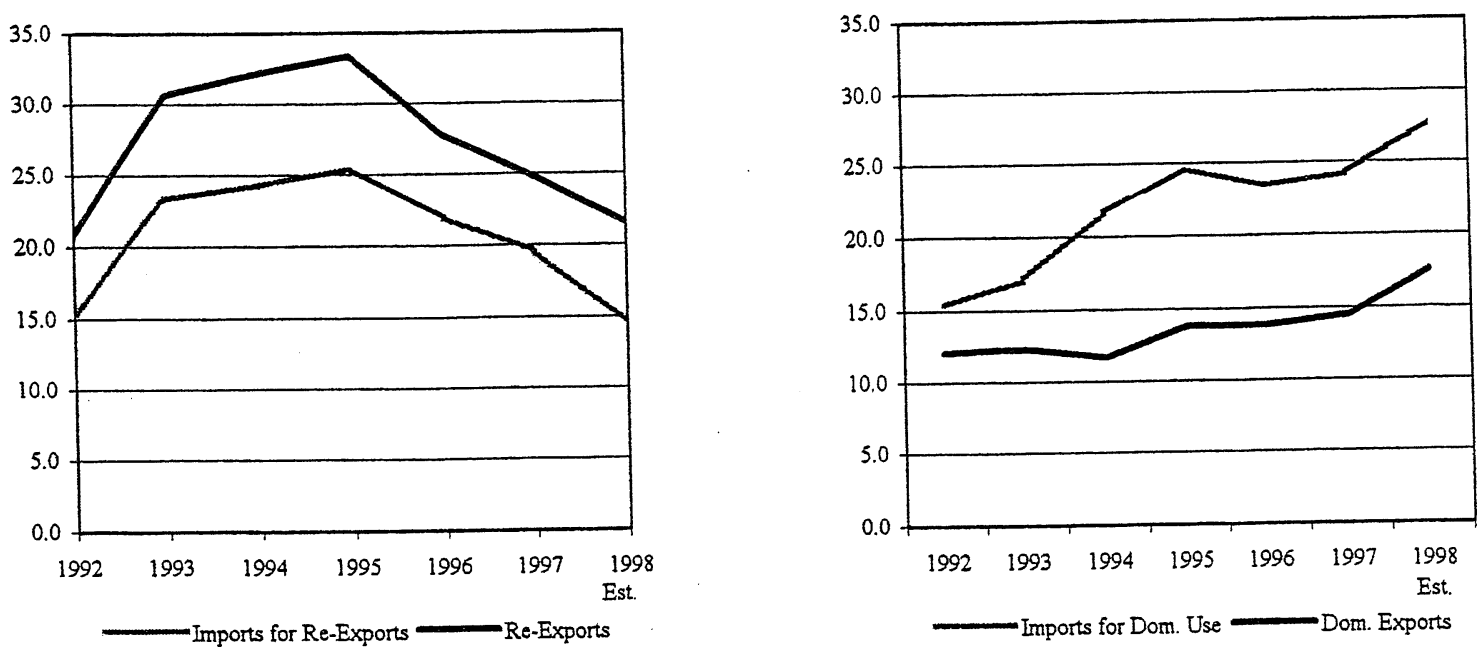

Foreign Direct Investment

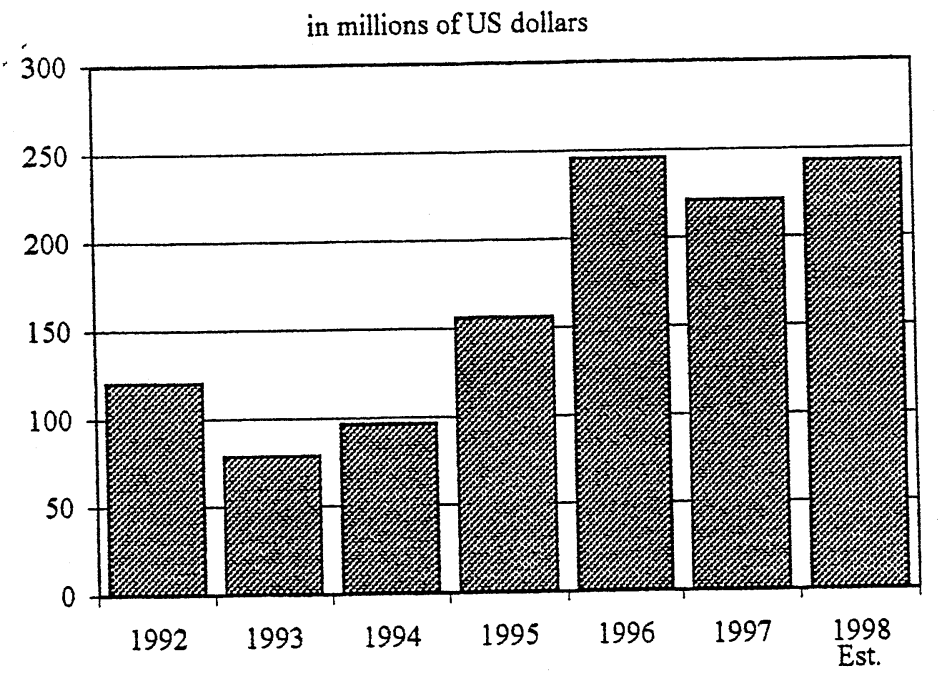


Paraguay into Mercosur in 1995 and the gradual convergence of tariff rates across the member countries have diminished the incentives for reexport trade, as have stricter controls along the brazilian border. Reexports have dropped to 21 percent of GDP by 1998 .

57. Since the value-added on reexports is estimated to be no more than 10 percent, their contribution to the external position of Paraguay has been rather modest. Figure 2 shows that the deterioration of the trade balance was mainly driven by a surge in imports for domestic use, and a sluggish performance of final exports. Between 1992 and 1998, imports for domestic markets almost doubled relative to GDP, from 15 to 28 percent. The steepest increase coincided with Paraguay's accession to Mercosur in 1995, and is consistent with the experience in other countries of the customs union.

58. Paraguayan exports also improved their performance, although at a slower pace. Their share in GDP rose from 12 percent in 1992 to just below 18 percent in 1998. This increase was based mainly on exports of primary agricultural products (Table 24). In 1997, 61 percent of registered exports consisted of primary products, and most of the rest were manufactures derived from primary inputs. There has been a significant shift from raw primary products to more value-added agricultural manufactures, which increased their share in exports from 17 percent in 1990 to 39 percent in 1997. The diversification and industrialization of paraguayan exports has certainly benefitted from increased inflows of foreign direct investment. In dollar terms, foreign direct investment rose threefold after Paraguay joined Mercosur, and is now almost sufficient to finance the current account deficit. Most foreign direct investment takes place in agriculture and banking, being supported by Law 60/90, which grants generous exemptions from profit taxes and the VAT for up to 10 years.

\section{The service, factor income and transfers account}

59. The service account of Paraguay has been in deficit during all of the last ten years. This is mostly due to a negative transport balance, which is closely linked to the reexport trade. Following a significant reduction in foreign debt, the factor income balance turned positive after 1993. The surplus was amplified by receipts of royalties from the Itaipú and Yacyretá hydroelectric dams-which Paraguay co-owns with Brazil and Argentina, respectively. Paraguay's transfer account is traditionally positive due to remittances of Paraguayans living abroad. Around 500,000 Paraguayans are living and working in Argentina and Brazil, and there is a large community in the United States.

\section{Public sector external debt}

60. The public sector's external debt is relatively low in Paraguay, having declined from 32 percent of GDP in 1990 to 16 percent in 1998. This decline was the result of the surpluses registered in the overall balance of the public sector until 1997 and a one-shot payment of the debt to Paris club members in 1992. Almost all paraguayan public debt is held by official institutions. Multilateral institutions-mainly the IDB-hold nearly $2 / 3$ of all public debt, 
whereas official bilateral creditors-especially Japan-hold the rest. Only 1 percent of the public debt is owed to commercial banks.

\section{The Exchange and Trade System}

61. Paraguay has a managed floating exchange rate regime, in which the $\mathrm{BCP}$ intervenes periodically in the currency market to avoid sharp swings in the value of the guarani, and adjusts the exchange rate broadly in line with the inflation differential with main trading partners. The real effective exchange rate appreciated by 2.4 percent in 1997, following an appreciation of 4.1 percent in 1996 . However, pressure on the exchange rate increased substantially in the final months of 1997 , and the BCP allowed the currency to depreciate more rapidly during January-April 1998. As a result, the real effective exchange rate depreciated by 9.6 percent in the first 8 months of 1998. However, it continues to be about 15 percent above its value during the 1989-1990 period, when the current account balance registered a small surplus.

62. Paraguay has a relatively free trade regime, with no quantitative restrictions on imports or exports. Paraguay implemented the Mercosur trade agreement in January 1995, eliminating most tariffs on trade with Argentina, Brazil and Uruguay, and adopting a common external tariff which ranges from 0 percent for raw materials and intermediate goods to 20 percent for luxury cars. Capital goods are subject to a 5 percent tariff, whereas most consumption goods are subject to a 10 percent tariff. Paraguay is allowed exemptions from the common external tariff for capital goods, telecommunication products, automotive products and 399 other selected items, consisting mostly of inputs to production and goods destined for the tourist industry. These exemptions are to be phased out gradually by January 2006. 
Table 1. Paraguay: National Accounts at Current Prices

\begin{tabular}{|c|c|c|c|c|c|c|c|}
\hline & 1992 & 1993 & 1994 & 1995 & 1996 & 1997 & $\begin{array}{r}\text { Est. } \\
1998 \\
\end{array}$ \\
\hline \multicolumn{8}{|c|}{ (In billions of guaranies) } \\
\hline Consumption expenditure & $7,573.5$ & $9,486.7^{\circ}$ & $11,858.4$ & $14,466.9$ & $16,250.6$ & $17,347.8$ & $19,790.7$ \\
\hline Public sector & 764.1 & $1,014.5$ & $1,283.0$ & $1,629.8$ & $1,967.0$ & $2,189.7$ & $2,493.0$ \\
\hline Private sector & $6,809.4$ & $8,472.3$ & $10,575.4$ & $12,837.1$ & $14,283.6$ & $15,158.1$ & $17,297.7$ \\
\hline Gross domestic investment & $2,009.8$ & $2,340.5$ & $3,494.1$ & $4,234.6$ & $4,635.1$ & $4,930.1$ & $4,981.6$ \\
\hline Public sector & 353.4 & 387.5 & 516.8 & 941.9 & 877.6 & $1,565.3$ & $1,615.1$ \\
\hline Private sector & $1,656.4$ & $1,953.0$ & $2,977.3$ & $3,292.8$ & $3,757.5$ & $3,364.8$ & $3,366,5$ \\
\hline Fixed capital formation & $1,912.1$ & $2,230.9$ & $3,366.5$ & $4,082.8$ & $4,478.4$ & $4,749.1$ & $4,777.8$ \\
\hline Changes in inventories & 97.6 & 109.6 & 127.7 & 151.8 & 156.7 & 181.0 & 203.8 \\
\hline Gross domestic expenditure & $9, \mathbf{5 8 3 . 2}$ & $11,827.2$ & $15,352.5$ & $18,701.5$ & $20,885.7$ & $22,277.9$ & $24,772.3$ \\
\hline External sector (G\&NFS) & 87.0 & 164.5 & -392.4 & $-1,002.9$ & -980.4 & $-1,343.5$ & $-1,050.4$ \\
\hline Exports of goods and nonfactor services & $3,865.1$ & $6,056.6$ & $7,470.7$ & $9,387.6$ & $9,380.1$ & $9,459.7$ & $10,668.7$ \\
\hline Imports of goods and nonfactor services & $-3,778.1$ & $-5,892.1$ & $-7,863.2$ & $-10,390.5$ & $-10,360.5$ & $-10,803.3$ & $-11,719.0$ \\
\hline GDP at market prices & $9,670.2$ & $11,991.7$ & $14,960.1$ & $17,698.6$ & $19,905.3$ & $20,934.4$ & $23,721.9$ \\
\hline \multicolumn{8}{|c|}{ (In percent of GDP) } \\
\hline Consumption expenditure & 78.3 & 79.1 & 79.3 & 81.7 & 81.6 & 82.9 & 83.4 \\
\hline Public sector & 7.9 & 8.5 & 8.6 & 9.2 & 9.9 & 10.5 & 10.5 \\
\hline Private sector & 70.4 & 70.7 & 70.7 & 72.5 & 71.8 & 72.4 & 72.9 \\
\hline Gross domestic investment & 20.8 & 19.5 & 23.4 & 23.9 & 23.3 & 23.6 & 21.0 \\
\hline Public sector & 3.7 & 3.2 & 3.5 & 5.3 & 4.4 & 7.5 & 6.8 \\
\hline Private sector & 17.1 & 16.3 & 19.9 & 18.6 & 18.9 & 16.1 & 14.2 \\
\hline Fixed capital formation & 19.8 & 18.6 & 22.5 & 23.1 & 22.5 & 22.7 & 20.1 \\
\hline Changes in inventories & 1.0 & 0.9 & 0.9 & 0.9 & 0.8 & 0.9 & 0.9 \\
\hline Gross domestic expenditure & 99.1 & 98.6 & 102.6 & 105.7 & 104.9 & 106.4 & 104.4 \\
\hline External sector (G\&NFS) & 0.9 & 1.4 & -2.6 & -5.7 & -4.9 & -6.4 & -4.4 \\
\hline Exports of goods and nonfactor services & 40.0 & 50.5 & 49.9 & 53.0 & 47.1 & 45.2 & 45.0 \\
\hline Imports of goods and nonfactor services & -39.1 & -49.1 & -52.6 & -58.7 & -52.0 & -51.6 & -49.4 \\
\hline GDP at market prices & 100.0 & 100.0 & 100.0 & 100.0 & 100.0 & 100.0 & 100.0 \\
\hline
\end{tabular}

Sources: Central Bank of Paraguay; and Fund staff estimates. 
Table 2. Paraguay: National Accounts at 1982 Prices

\begin{tabular}{|c|c|c|c|c|c|c|c|}
\hline & 1992 & 1993 & 1994 & 1995 & $1996^{\circ}$ & 1997 & $\begin{array}{r}\text { Est. } \\
1998 \\
\end{array}$ \\
\hline & \multicolumn{7}{|c|}{ (In millions of 1982 guaranies) } \\
\hline Consumption expenditure & 937.1 & $1,010.6$ & $1,080.8$ & $1,104.4$ & $1,121.5$ & $1,162.6$ & $1,153.8$ \\
\hline Public sector & 75.2 & 83.0 & 89.9 & 100.7 & 110.7 & 115.1 & 117.1 \\
\hline Private sector & 861.9 & 927.7 & 990.9 & $1,003.8$ & $1,010.9$ & $1,047.5$ & $1,036.7$ \\
\hline Gross domestic investment & 201.5 & 195.5 & 259.4 & 276.5 & 276.2 & 269.4 & 238.7 \\
\hline Fixed capital formation & 192.3 & 187.1 & 237.7 & 254.6 & 254.3 & 249.1 & 218.2 \\
\hline Changes in inventories $1 /$ & 9.2 & 8.4 & 21.7 & 21.9 & 21.8 & 20.3 & 20.4 \\
\hline Gross domestic expenditure & $1,138.6$ & $1,206.1$ & $1,340.2$ & $1,380.9$ & $1,397.7$ & $1,432.1$ & $1,392.4$ \\
\hline External Sector (G\&NFS) & -171.3 & -198.7 & -301.7 & -293.5 & -296.5 & -302.4 & -256.0 \\
\hline Exports of goods and nonfactor services & 278.9 & 315.7 & 307.6 & 393.3 & 395.3 & 440.8 & 456.7 \\
\hline Imports of goods and nonfactor services & -450.1 & -514.5 & -609.3 & .686 .8 & -691.7 & $-743,2$ & -712.7 \\
\hline GDP at market prices & 967.3 & $1,007.4$ & $1,038.5$ & $1,087.4$ & $1,101.2$ & $1,129.7$ & $1,136.5$ \\
\hline \multicolumn{8}{|c|}{ (Percentage change) } \\
\hline Consumption expenditure & -2.2 & 7.8 & 6.9 & 2.2 & 1.5 & 3.7 & -0.8 \\
\hline Public sector & 8.7 & 10.3 & 8.3 & 12.0 & 9.9 & 4.0 & 1.7 \\
\hline Private sector & -3.1 & 7.6 & 6.8 & 1.3 & 0.7 & 3.6 & -1.0 \\
\hline Gross domestic investment & -11.1 & -3.0 & 32.7 & 6.6 & -0.1 & -2.4 & -11.4 \\
\hline Fixed capital formation & -11.5 & -2.7 & 27.0 & 7.1 & -0.1 & -2.0 & -12.4 \\
\hline Changes in inventories $1 /$ & 0.0 & -0.1 & 1.3 & 0.0 & 0.0 & -0.1 & 0.0 \\
\hline Gross domestic expenditure & -3.9 & 5.9 & 11.1 & 3.0 & 1.2 & 2.5 & -2.8 \\
\hline Net exports 1/ & 6.7 & -2.8 & -10.2 & 0.8 & -0.3 & -0.5 & 4.1 \\
\hline Exports of goods and nonfactor services & -1.3 & 13.2 & -2.6 & 27.8 & 0.5 & 11.5 & 3.6 \\
\hline Imports of goods and nonfactor services & -13.0 & 14.3 & 18.4 & 12.7 & 0.7 & 7.4 & -4.1 \\
\hline GDP at market prices & 1.8 & 4.1 & 3.1 & 4.7 & 1.3 & 2.6 & 0.6 \\
\hline
\end{tabular}

Sources: Central Bank of Paraguay; and Fund staff estimates.

1/ Contribution to GDP growth. 
Table 3. Paraguay: Savings-Investment Balance

(In percent of GDP)

\begin{tabular}{|c|c|c|c|c|c|c|c|}
\hline . & 1992 & 1993 & 1994 & 1995 & 1996 & 1997 & $\begin{array}{r}\text { Est. } \\
1998 \\
\end{array}$ \\
\hline GDP at market prices & 100.0 & 100.0 & 100.0 & 100.0 & 100.0 & 100.0 & 100.0 \\
\hline Domestic expenditure & 99.1 & 98.6 & 102.6 & 105.7 & 104.9 & 106.4 & 104.5 \\
\hline Consumption & 78.3 & 79.1 & 79.3 & 81.7 & 81.6 & 82.9 & 83.5 \\
\hline Public sector & 7.9 & 8.5 & 8.6 & 9.2 & 9.9 & 10.5 & 10.6 \\
\hline Private sector & 70.4 & 70.7 & 70.7 & 72.5 & 71.8 & 72.4 & 72.9 \\
\hline Gross domestic investment & 20.8 & 19.5 & 23.4 & 23.9 & 23.3 & 23.6 & 21.0 \\
\hline Public sector & 3.7 & 3.2 & 3.5 & 5.3 & 4.4 & 7.5 & 6.9 \\
\hline Private sector & 17.1 & 16.3 & 19.9 & 18.6 & 18.9 & 16.1 & 14.1 \\
\hline Gross national savings & 22.1 & 23.1 & 22.6 & 19.9 & 20.0 & 18.5 & 17.9 \\
\hline Public sector $1 /$ & 3.6 & 4.3 & 4.9 & 7.8 & 6.1 & 6.7 & 5.6 \\
\hline Private sector & 18.5 & 18.8 & 17.7 & 12.1 & 13.9 & 11.9 & 12.3 \\
\hline Current account balance & 1.3 & 3.6 & -0.7 & -4.1 & -3.3 & -5.0 & -3.1 \\
\hline Public sector overall balance & 0.0 & 1.1 & 1.5 & 2.5 & 1.7 & -0.8 & -1.2 \\
\hline Private savings-investment balance & 1.4 & 2.5 & -2.2 & -6.5 & -4.9 & -4.2 & -1.9 \\
\hline
\end{tabular}

Source: Central Bank of Paraguay; and Fund staff estimates. 
Table 4. Paraguay: GDP by Sector of Origin at Current Prices

\begin{tabular}{|c|c|c|c|c|c|c|c|}
\hline & 1992 & 1993 & 1994 & 1995 & 1996 & 1997 & $\begin{array}{r}\text { Est. } \\
1998 \\
\end{array}$ \\
\hline \multicolumn{8}{|c|}{ (In billions of guaranies) } \\
\hline GDP at market prices & $9,670.2$ & $11,991.7$ & $14,960.1$ & $17,698.6$ & $19,905.3$ & $20,934.4$ & $23,721.9$ \\
\hline Agriculture, hunting, and fishing & $1,467.7$ & $1,865.8$ & $2,209.2$ & $2,774.4$ & $3,354.7$ & $3,201.5$ & $3,684.7$ \\
\hline Livestock & 640.3 & 747.9 & 901.5 & $1,072.2$ & $1,106.7$ & $1,278.4$ & $1,483.3$ \\
\hline Forestry & 261.1 & 325.9 & 439.7 & 540.4 & 587.0 & 640.8 & 735.3 \\
\hline Manufacturing & $1,643.2$ & $1,979.5$ & $2,352.0$ & $2,769.7$ & $3,062.6$ & $3,193.1$ & $3,631.9$ \\
\hline Construction & 558.9 & 709.5 & 898.3 & $1,053.7$ & $1,199.3$ & $1,308.2$ & $1,503.7$ \\
\hline Utilities & 301.7 & 407.1 & 585.8 & 762.4 & 889.4 & 913.2 & $1,078.0$ \\
\hline Transport and communications & 384.7 & 470.2 & 584.1 & 650.6 & 729.4 & 808.1 & 937.7 \\
\hline Commerce and finance & $2,929.9$ & $3,646.3$ & $4,558.4$ & $5,217.2$ & $5,598.1$ & $5,787.4$ & $6,323.1$ \\
\hline General Government & 402.2 & 507.7 & 638.3 & 774.6 & 930.2 & $1,065.4$ & $1,103.6$ \\
\hline Other $1 /$ & $1,080.6$ & $1,331.9$ & $1,792.8$ & $2,083.4$ & $2,447.9$ & $2,738.3$ & $3,240.6$ \\
\hline \multicolumn{8}{|c|}{ (In percent of GDP) } \\
\hline GDP at market prices & 100.0 & 100.0 & 100.0 & 100.0 & 100.0 & 100.0 & 100.0 \\
\hline Agriculture, hunting, and fishing & 15.2 & 15.6 & 14.8 & 15.7 & 16.9 & 15.3 & 15.5 \\
\hline Livestock & 6.6 & 6.2 & 6.0 & 6.1 & 5.6 & 6.1 & 6.3 \\
\hline Forestry & 2.7 & 2.7 & 2.9 & 3.1 & 2.9 & 3.1 & 3.1 \\
\hline Manufacturing & 17.0 & 16.5 & 15.7 & 15.6 & 15.4 & 15.3 & 15.3 \\
\hline Construction & 5.8 & 5.9 & 6.0 & 6.0 & 6.0 & 6.2 & 6.3 \\
\hline Utilities & 3.1 & 3.4 & 3.9 & 4.3 & 4.5 & 4.4 & 4.5 \\
\hline Transport and communications & 4.0 & 3.9 & 3.9 & 3.7 & 3.7 & 3.9 & 4.0 \\
\hline Commerce and finance & 30.3 & 30.4 & 30.5 & 29.5 & 28.1 & 27.6 & 26.7 \\
\hline General Government & 4.2 & 4.2 & 4.3 & 4.4 & 4.7 & 5.1 & 4.7 \\
\hline Other $1 /$ & 11.2 & 11.1 & 12.0 & 11.8 & 12.3 & 13.1 & 13.7 \\
\hline
\end{tabular}

Sources: Central Bank of Paraguay; and Fund staff estimates. 
Table 5. Paraguay: GDP by Sector of Origin at Constant 1982 Prices

\begin{tabular}{|c|c|c|c|c|c|c|c|}
\hline \multicolumn{8}{|c|}{ (In millions of 1982 guaranies) } \\
\hline GDP at market prices & 967.3 & $1,007.4$ & $1,038.5$ & $1,087.4$ & $1,101.2$ & $1,129.7$ & $1,136.4$ \\
\hline Agriculture, hunting, and fishing & 151.4 & 162.8 & 158.0 & 176.0 & 178.1 & 186.8 & 192.4 \\
\hline Livestock & 75.1 & 77.1 & 79.4 & 81.9 & 83.3 & 87.9 & 90.5 \\
\hline Forestry & 27.6 & 28.3 & 29.2 & 30.1 & 30.4 & 31.0 & 31.6 \\
\hline Manufacturing & 151.3 & 154.3 & 156.6 & 161.3 & 157.8 & 157.5 & 159.0 \\
\hline Construction & 52.4 & 53.9 & 55.8 & 58.0 & 59.8 & 60.4 & 61.6 \\
\hline Utilities & 36.2 & 41.4 & 49.9 & 57.2 & 60.7 & 62.9 & 65.9 \\
\hline Transport and communications & 45.8 & 47.3 & 49.2 & 50.9 & 52.2 & 54.2 & 55.8 \\
\hline Commerce and finance & 257.0 & 266.8 & 278.2 & 282.6 & 279.8 & 280.3 & 271.9 \\
\hline General Government & 46.4 & 48.4 & 51.5 & 55.2 & 60.7 & 64.9 & 59.7 \\
\hline Other $1 /$ & 124.2 & 127.1 & 130.7 & 134.2 & 138.4 & 143.9 & 148.0 \\
\hline \multicolumn{8}{|c|}{ (Percentage change) } \\
\hline GDP at market prices & 1.8 & 4.1 & 3.1 & 4.7 & 1.3 & 2.6 & 0.6 \\
\hline Agriculture, hunting, and fishing & -1.3 & 7.6 & -3.0 & 11.4 & 1.2 & 4.9 & 3.0 \\
\hline Livestock & 1.3 & 2.7 & 3.0 & 3.1 & 1.7 & 5.5 & 3.0 \\
\hline Forestry & 4.7 & 2.5 & 3.4 & 3.1 & 1.0 & 2.0 & 1.9 \\
\hline Manufacturing & 0.4 & 2.0 & 1.5 & 3.0 & -2.2 & -0.2 & 1.0 \\
\hline Construction & 5.0 & 2.7 & 3.6 & 3.9 & 3.1 & 0.9 & 2.1 \\
\hline Utilities & 10.8 & 14.1 & 20.6 & 14.6 & 6.1 & 3.6 & 4.8 \\
\hline Transport and communications & 2.5 & 3.4 & 4.0 & 3.5 & 2.6 & 3.8 & 3,0 \\
\hline Commerce and finance & 0.6 & 3.8 & 4.3 & 1.6 & -1.0 & 0.2 & -3.0 \\
\hline General Government & 7.8 & 4.3 & 6.4 & 7.2 & 10.0 & 6,9 & -8.0 \\
\hline Other $1 /$ & 3.5 & 2.4 & $2.8^{\circ}$ & 2.7 & 3.1 & 4.0 & 2.9 \\
\hline
\end{tabular}

Sources: Central Bank of Paraguay; and Fund staff estimates. 
Table 6. Paraguay: Volume of Agricultural Production 1/

\begin{tabular}{|c|c|c|c|c|c|c|}
\hline & 1992 & 1993 & 1994 & 1995 & 1996 & 1997 \\
\hline \multicolumn{7}{|c|}{$(1982=100)$} \\
\hline Wheat & 462.1 & 598.6 & 528.6 & 293.5 & 764.6 & 563.4 \\
\hline Corn & 272.6 & 266.2 & 279.9 & 494.8 & 396.5 & 639.5 \\
\hline Rice & 171.2 & 247.7 & 259.4 & 289.5 & 281.4 & 301.5 \\
\hline Manioc & 58.0 & 59.5 & 56.4 & 68.4 & 61.7 & 77.7 \\
\hline Soybeans & 292.9 & 324.7 & 325.1 & 400.5 & 433.6 & 483.5 \\
\hline Sugarcane & 148.4 & 149.7 & 149.0 & 145.6 & 154.6 & 157.0 \\
\hline Cotton & 183.2 & 196.9 & 177.8 & 215.9 & 154.4 & 65.7 \\
\hline Oranges & 76.7 & 77.4 & 74.2 & 74.6 & 75.0 & 82.0 \\
\hline Tomatoes & 135.5 & 139.7 & 128.2 & 132.1 & 136.4 & 141.6 \\
\hline Beans & 22.6 & 25.4 & 25.6 & 35.7 & 35.0 & 44.8 \\
\hline Bananas & 81.3 & 81.9 & 69.0 & 63.5 & 60.8 & 64.0 \\
\hline \multicolumn{7}{|c|}{ (Percentage change) } \\
\hline \multicolumn{7}{|c|}{ Memorandum items } \\
\hline Wheat & 26.6 & 29.5 & -11.7 & -44.5 & 160.5 & -26.3 \\
\hline Corn & 12.0 & -2.3 & 5.1 & 76.8 & -19.9 & 61.3 \\
\hline Soybeans & 56.6 & 10.9 & 0.1 & 23.2 & 8.3 & 11.5 \\
\hline Cotton & -38.0 & 7.5 & -9.7 & 21.4 & -28.5 & -57.4 \\
\hline
\end{tabular}

Sources: Central Bank of Paraguay; and Fund Staff estimates.

1/ Agricultural years; for example, 1991 refers to the 1990/91 agricultural year. 
Table 7. Paraguay: Value of Agricultural Production 1/

\begin{tabular}{|c|c|c|c|c|c|c|c|}
\hline & 1991 & 1992 & 1993 & 1994 & 1995 & 1996 & 1997 \\
\hline \multicolumn{8}{|c|}{ (In billions of guaranies) } \\
\hline Total production & $1,550.2$ & $1,628.1$ & $2,067.6$ & $2,447.5$ & $3,030.9$ & $3,628.1$ & $3,457.8$ \\
\hline Wheat & 42.3 & 67.3 & 88.1 & 78.5 & 54.4 & 156.4 & 77.2 \\
\hline Corn & 115.6 & 127.8 & 144.5 & 194.8 & 334.2 & 429.8 & 350.5 \\
\hline Rice & 16.0 & 18.4 & 22.0 & 30.7 & 41.3 & 34.9 & 36.0 \\
\hline Manioc & 294.7 & 274.2 & 302.8 & 380.2 & 574.2 & 667.4 & 530.0 \\
\hline Soybeans & 195.2 & 377.3 & 557.8 & 635.7 & 663.7 & $1,022.1$ & $1,321.7$ \\
\hline Cotton & 314.3 & 165.9 & 257.9 & 296.7 & 433.5 & 238.7 & 128.2 \\
\hline Other & 572.1 & 597.2 & 694.5 & 830.9 & 929.6 & $1,078.8$ & $1,014.2$ \\
\hline \multicolumn{8}{|c|}{ (Percentage distribution) } \\
\hline Total production & 100.0 & 100.0 & 100.0 & 100.0 & 100.0 & 100.0 & 100.0 \\
\hline Wheat & 2.7 & 4.1 & 4.3 & 3.2 & 1.8 & 4.3 & 2.2 \\
\hline Corn & 7.5 & 7.8 & 7.0 & 8.0 & 11.0 & 11.8 & 10.1 \\
\hline Rice & 1.0 & 1.1 & 1.1 & 1.3 & 1.4 & 1.0 & 1.0 \\
\hline Manioc & 19.0 & 16.8 & 14.6 & 15.6 & 18.9 & 18.4 & 15.3 \\
\hline Soybeans & 12.6 & 23.2 & 27.0 & 26.0 & 22.0 & 28.2 & 38.2 \\
\hline Cotton & 20.3 & 10.2 & 12.5 & 12.1 & 14.3 & 6.6 & 3.7 \\
\hline Other & 36.9 & 36.8 & 33.5 & 33.8 & 30.6 & 29.7 & 29.3 \\
\hline
\end{tabular}

Sources: Central Bank of Paraguay; and Fund staff estimates.

1/ Agricultural years; for example, 1991 refers to the 1990/91 agricultural year. 
Table 8. Paraguay: Production, Area Cultivated and Yields of Selected Crops 1/2/ (Production in metric tons; area in thousands of hectares; yields in $\mathrm{kg} /$ hectare)

\begin{tabular}{|c|c|c|c|c|c|c|}
\hline & 1992 & 1993 & 1994 & 1995 & 1996 & 1997 \\
\hline \multicolumn{7}{|l|}{ Corn } \\
\hline Production & 449,700 & 439,145 & 461,665 & 816,166 & 654,074 & $1,055,661$ \\
\hline Area & 258 & 249 & 218 & 331 & 325 & 384 \\
\hline Yield & 1,743 & 1,763 & 2,114 & 2,466 & 2,015 & 2,749 \\
\hline \multicolumn{7}{|l|}{ Cotton } \\
\hline Production & 391,380 & 420,772 & 379,877 & 461,239 & 329,751 & 139,096 \\
\hline Area & 437 & 421 & 381 & 332 & 307 & 111 \\
\hline Yield & 895 & 999 & 997 & 1,389 & 1,075 & 1,253 \\
\hline \multicolumn{7}{|l|}{ Manioc } \\
\hline Production & $2,591,320$ & $2,655,962$ & $2,517,970$ & $3,054,394$ & $\begin{array}{r}2,757,358 \\
191\end{array}$ & $3,155,000$ \\
\hline Area & 179 & 184 & 174 & 211 & 191 & 220 \\
\hline Yield & 14,448 & 14,448 & 14,448 & 14,448 & 14,448 & 14,341 \\
\hline \multicolumn{7}{|l|}{ Rice } \\
\hline Production & 53,990 & 78,125 & 81,809 & 91,293 & 88,747 & 94,858 \\
\hline Area & 18 & 24 & 24 & 26 & 27 & 29 \\
\hline Yield & 2,999 & 3,237 & 3,387 & 3,497 & 3,252 & 3,271 \\
\hline \multicolumn{7}{|l|}{ Soybeans } \\
\hline Production & $1,192,074$ & $1,793,544$ & $1,795,792$ & $2,212,109$ & $2,394,794$ & $2,670,003$ \\
\hline Area & 595 & 635 & 694 & 736 & 833 & 940 \\
\hline Yield & 2,004 & 2,825 & 2,587 & 3,008 & 2,875 & 2,840 \\
\hline \multicolumn{7}{|l|}{ Sugarcane } \\
\hline Production & $2,788,210$ & $2,811,460$ & $2,799,318$ & $2,576,000$ & $\begin{array}{r}2,736,000 \\
57\end{array}$ & $\begin{array}{r}2,795,000 \\
58\end{array}$ \\
\hline Area & 56 & 56 & 56 & 56 & & $\begin{array}{r}58 \\
48.190\end{array}$ \\
\hline Yield & 49,870 & 50,258 & 50,314 & 46,000 & 48,000 & 48,190 \\
\hline \multicolumn{7}{|l|}{ Tobaceo } \\
\hline Production & 8,300 & 8,471 & 8,520 & 6,945 & 8,156 & 14,024 \\
\hline Area & 4 & 5 & 5 & 5 & 5 & 8 \\
\hline Yield & 1,878 & 1,872 & 1,878 & 1,534 & 1,631 & 1,753 \\
\hline \multicolumn{7}{|l|}{ Wheat } \\
\hline Production & 328,406 & 425,421 & 375,679 & 208,617 & 543,435 & 400,189 \\
\hline Area & 183 & 192 & 175 & 172 & 221 & 224 \\
\hline Yield & 1,797 & 2,213 & 2,149 & 1,209 & 2,454 & 1,787 \\
\hline
\end{tabular}

Sources: Ministry of Agriculture; and Fund staff estimates.

1/ Agricultural years; for example, 1991 refers to the 1990/91 agricultural year. Data include seeds. 2/ Data may not fully agree with those in Table 8 because of differences in sources and methodology. 
Table 9. Paraguay: Value-Added in Manufacturing

\begin{tabular}{|c|c|c|c|c|c|c|}
\hline & 1992 & 1993 & 1994 & 1995 & 1996 & 1997 \\
\hline \multicolumn{7}{|c|}{ (In billions of 1982 guaranies) } \\
\hline All industries & 151.3 & 154.3 & 156.6 & 161.3 & 157.7 & 157.5 \\
\hline $\begin{array}{l}\text { Light consumer industries } \\
\text { Of which: Foodstuffs }\end{array}$ & 87.2 & 86.3 & 91.4 & 95.3 & 95.1 & 98.9 \\
\hline $\begin{array}{c}\text { Of which: Foodstuffs } \\
\text { Beverages }\end{array}$ & 52.1 & 49.8 & 53.2 & 54.1 & 55.1 & 56.9 \\
\hline $\begin{array}{l}\text { Beverages } \\
\text { Shoes }\end{array}$ & 12.0 & 13.8 & 15.2 & 16.7 & 16.6 & 17.5 \\
\hline $\begin{array}{l}\text { Shoes } \\
\text { Handicrafts }\end{array}$ & 3.1 & 2.5 & 1.9 & 2.0 & 2.2 & 2.2 \\
\hline $\begin{array}{l}\text { Handicrafts } \\
\text { Printing and publishing }\end{array}$ & 10.9 & 10.5 & 10.8 & 11.5 & 10.2 & 10.2 \\
\hline $\begin{array}{l}\text { Printing and publishing } \\
\text { Others }\end{array}$ & 5.5 & 6.6 & 7.1 & 7.8 & 8.1 & 9.0 \\
\hline Intermediate products & 3.5 & 3.2 & 3.2 & 3.2 & 2.9 & 3.1 \\
\hline $\begin{array}{l}\text { Intermediate products } \\
\text { Of which: Wood and lumber }\end{array}$ & 61.5 & 65.9 & 63.9 & 64.6 & 61.3 & 58.6 \\
\hline $\begin{array}{c}\text { Of which: Wood and lumber } \\
\text { Textiles }\end{array}$ & 19.9 & 21.0 & 23.2 & 24.5 & 23.5 & 24.7 \\
\hline $\begin{array}{l}\text { Textiles } \\
\text { Leather and hides }\end{array}$ & 10.1 & 10.2 & 9.2 & 10.2 & 8.1 & 4.9 \\
\hline $\begin{array}{l}\text { Leather and hides } \\
\text { Petroleum derivatives }\end{array}$ & 4.7 & 5.9 & 5.6 & 6.1 & 7.3 & 7.1 \\
\hline $\begin{array}{l}\text { Petroleum derivatives } \\
\text { Nonmetallic mineral products }\end{array}$ & 10.7 & 8.6 & 8.8 & 6.4 & 5.0 & 4.1 \\
\hline $\begin{array}{l}\text { Nonmetallic mineral products } \\
\text { Metallic products }\end{array}$ & 6.2 & 6.4 & 6.0 & 6.9 & 6.9 & 6.7 \\
\hline Others & 2.1 & 1.8 & 1.0 & 1.0 & 1.0 & 1.0 \\
\hline & 7.9 & 12.1 & 10.0 & 9.5 & 9.3 & 10.1 \\
\hline \multirow{2}{*}{\multicolumn{7}{|c|}{ (Percentage change) }} \\
\hline All industries & & & & & & \\
\hline & 0.4 & 2.0 & 1.5 & 3.0 & -2.2 & -0.1 \\
\hline $\begin{array}{l}\text { Light consumer industries } \\
\text { Of which: Foodstuffs }\end{array}$ & -0.3 & & 5.8 & 4.3 & -0.3 & 4.0 \\
\hline Beverages & 10.8 & $\begin{array}{r}-4.4 \\
14.4\end{array}$ & $\begin{array}{r}6.7 \\
10.7\end{array}$ & 1.7 & 1.8 & 3.3 \\
\hline Shoes & -1.4 & $\begin{array}{r}14.4 \\
-19.2\end{array}$ & $\begin{array}{r}10.7 \\
-24.7\end{array}$ & $\begin{array}{l}9.7 \\
4.8\end{array}$ & -0.2 & 5.4 \\
\hline Handicrafts & -17.3 & -4.0 & 2.7 & $\begin{array}{l}4.8 \\
6.4\end{array}$ & 10.0 & 0.0 \\
\hline Printing and publishing & $\begin{array}{r}-27.5 \\
17.1\end{array}$ & 20.0 & 8.6 & $\begin{array}{r}6.4 \\
10.3\end{array}$ & -11.5 & 0.0 \\
\hline Others & $\begin{array}{r}17.1 \\
-24.7\end{array}$ & -9.1 & -1.3 & $\begin{array}{r}10.3 \\
0.8\end{array}$ & 3.9 & 11.1 \\
\hline Intermediate products & & 7.1 & & 0.8 & -10.8 & 6.9 \\
\hline Of which: Wood and lumber & $\begin{array}{r}2.2 \\
12.7\end{array}$ & 5.6 & -3.1 & 1.1 & -5.2 & -4.4 \\
\hline Textiles & 3.5 & 0.3 & 10.7 & 5.8 & -4.1 & 5.1 \\
\hline Leather and hides & 63.9 & 25.2 & -9.7 & 10.8 & -20.3 & -39.5 \\
\hline Petroleum derivatives & -14.8 & -19.2 & -5.1 & 9.3 & 18.9 & -2.7 \\
\hline Nonmetallic mineral products & 2.6 & 3.8 & 2.3 & -27.7 & -21.2 & -18.0 \\
\hline Metallic products & -17.0 & -17.4 & -6.1 & 15.2 & 0.5 & -2.9 \\
\hline Others & -11.0 & 54.0 & -42.2 & 1.8 & -0.8 & 0.0 \\
\hline Machinery, appliances and transport & & & -17.2 & -5.1 & -1.6 & 8.6 \\
\hline 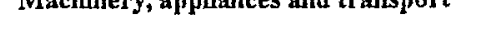 & -16.2 & -21.2 & -31.6 & -0.9 & 0.0 & -0.9 \\
\hline \multicolumn{7}{|c|}{ (Percentage distribution) } \\
\hline All industries & 100.0 & 100.0 & 100.0 & 100.0 & 100.0 & 100.0 \\
\hline Light consumer industries & 57.6 & 56.0 & 58.3 & 59.1 & 60.3 & 62.8 \\
\hline Of which: Foodstuffs. & 34.4 & 32.3 & 34.0 & 33.5 & 34.9 & 36.1 \\
\hline Beverages. & 8.0 & 8.9 & 9.7 & 10.3 & 10.6 & 11.1 \\
\hline Shoes & 2.1 & 1.6 & 1.2 & 1.2 & 1.4 & 1.4 \\
\hline Handicrafts & 7.2 & 6.8 & 6.9 & 7.1 & 6.4 & 6.5 \\
\hline Printing and publishing & 3.6 & 4.3 & 4.6 & 4.9 & 5.2 & 5.7 \\
\hline Others & 2.3 & 2.1 & 2.0 & 2.0 & 1.8 & 2.0 \\
\hline Intermediate products & 40.7 & 42.7 & 40.8 & 40.1 & 38.8 & 37.2 \\
\hline Of which: Wood and lumber & 13.1 & 13.6 & 14.8 & 15.2 & 14.9 & 15.7 \\
\hline Textiles & 6.7 & 6.6 & 5.9 & 6.3 & 5.2 & 3.1 \\
\hline Leather and hides & 3.1 & 3.8 & 3.6 & 3.8 & 4.6 & 4.5 \\
\hline Petroleum derivatives & 7.0 & 5.6 & 3.6 & 3.9 & 3.2 & 2.6 \\
\hline Nonmetallic mineral products & 4.1 & 4.2 & 3.8 & 4.3 & 4.4 & 4.3 \\
\hline Metallic products & 1.4 & 1.1 & 0.6 & 0.6 & 0.6 & 0.6 \\
\hline Others & 5.2 & 7.8 & 6.4 & 5.9 & 5.9 & 6.4 \\
\hline Machinery, appliances \& transport & 1.7 & 1.3 & 0.9 & 0.9 & 0.9 & 0.9 \\
\hline
\end{tabular}


Table 10. Paraguay: Consumer Price Movements in Asunción 1/

(Annual percentage change)

\begin{tabular}{lrrrrr}
\hline & Food & Housing & Clothing & Other & All Items \\
\hline Weights & 37.0 & 27.7 & 9.0 & 26.3 & 100.0 \\
& & & & & \\
& & I. Average & & & \\
1992 & 14.9 & 14.7 & 10.9 & 17.3 & 15.5 \\
1993 & 17.3 & 18.5 & 12.4 & 21.5 & 18.3 \\
1994 & 20.4 & 20.2 & 14.2 & 23.1 & 20.6 \\
1995 & 13.8 & 14.3 & 13.7 & 12.2 & 13.4 \\
1996 & 6.3 & 13.8 & 6.4 & 13.2 & 9.8 \\
1997 & 4.4 & 9.1 & 3.5 & 9.8 & 7.0
\end{tabular}

II. End-of-Period

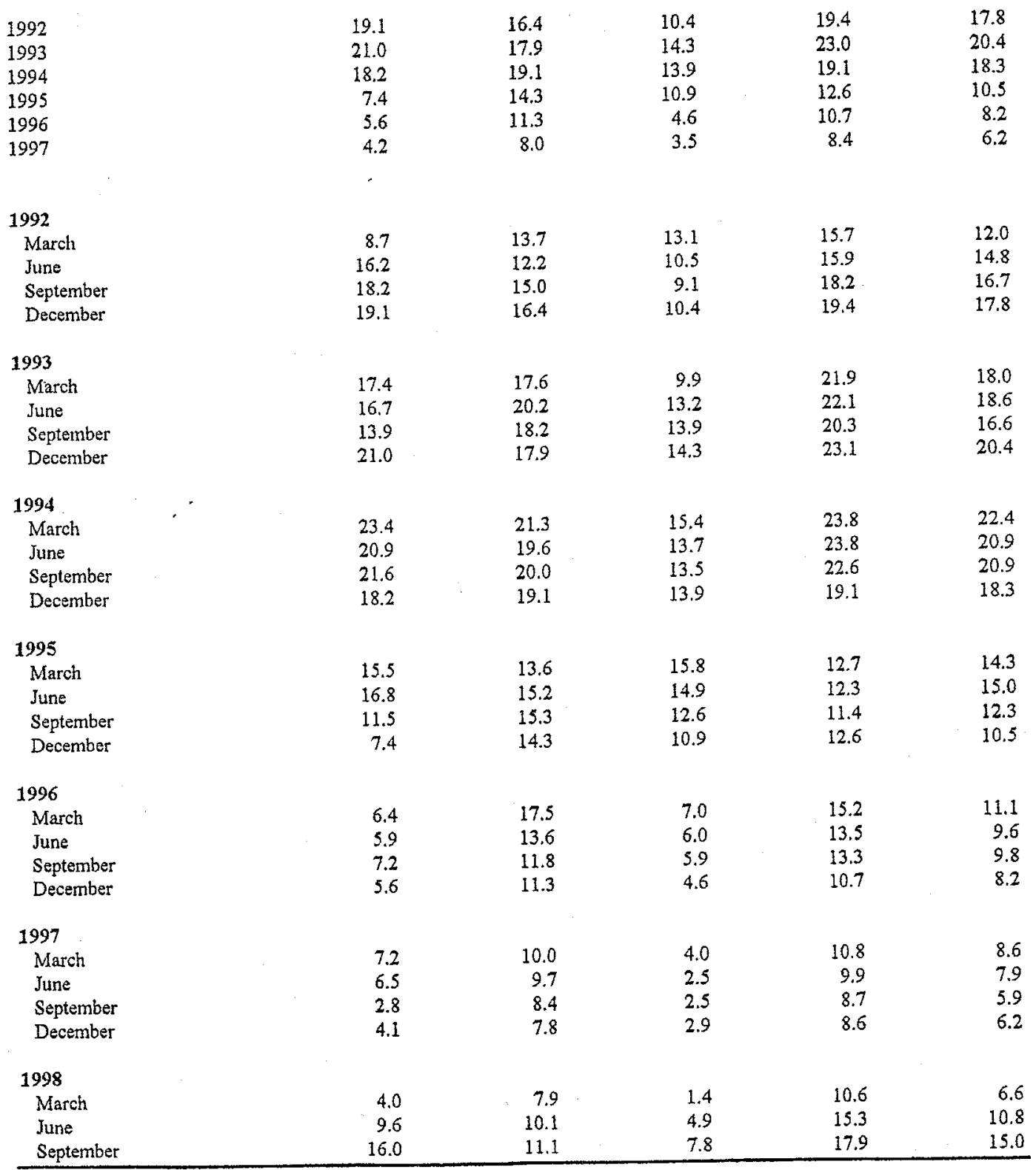

Source: Central Bank of Paraguay.

1/ Refers to the metropolitan area, including Asunción and 14 other municipalities. 
Table 11. Paraguay: Producer Prices

\begin{tabular}{|c|c|c|c|}
\hline & Domestic Products & Imported Products & Total \\
\hline \multicolumn{4}{|c|}{ I. Index } \\
\hline \multicolumn{4}{|l|}{1995} \\
\hline December & 100.0 & 100.0 & 100.0 \\
\hline \multicolumn{4}{|l|}{1996} \\
\hline March & 107.7 & 104.7 & 106.8 \\
\hline June & 108.3 & 105.6 & 107.5 \\
\hline September & 110.2 & 106.2 & 109.0 \\
\hline December & 109.0 & 106.6 & 108.3 \\
\hline \multicolumn{4}{|l|}{1997} \\
\hline March & 107.3 & 107.0 & 107.2 \\
\hline June & 107.8 & 108.1 & 107.9 \\
\hline September & 107.8 & 108.8 & 108.1 \\
\hline December & 109.5 & 111.9 & 110.2 \\
\hline \multicolumn{4}{|l|}{1998} \\
\hline March & 115.1 & 119.1 & 116.3 \\
\hline June & 123.5 & 124.0 & 123.6 \\
\hline \multicolumn{4}{|c|}{ II. Annual percentage change } \\
\hline \multicolumn{4}{|c|}{ 然 1} \\
\hline March & -0.4 & 2.2 & 0.4 \\
\hline June & -0.5 & 2.4 & 0.4 \\
\hline September & -2.2 & 2.4 & -0.8 \\
\hline December & 0.5 & 5.0 & 1.8 \\
\hline \multicolumn{4}{|l|}{1998} \\
\hline March & 7.3 & 11.3 & 8.5 \\
\hline June & 14.6 & 14.7 & 14.6 \\
\hline
\end{tabular}

Source: Central Bank of Paraguay. 
Table 12. Paraguay: Labor Market Indicators $1 /$

\begin{tabular}{|c|c|c|c|c|c|c|}
\hline & 1992 & 1993 & 1994 & 1995 & 1996 & 1997 \\
\hline \multicolumn{7}{|c|}{ I. Wage Indices, End-of-Period } \\
\hline \multicolumn{7}{|c|}{$(1980=100)$} \\
\hline \multicolumn{7}{|l|}{ Nominal wage indices } \\
\hline Wages & $1,084.1$ & $1,299.7$ & $1,600.8$ & $1,893.7$ & $2,100.1$ & $2,249.6$ \\
\hline Private sector minimum wage & $1,165.6$ & $1,325.0$ & $1,641.7$ & $1,891.0$ & $2,126.2$ & $2,393.3$ \\
\hline \multicolumn{7}{|l|}{ Real wage indices $2 /$} \\
\hline Wages & 99.7 & 99.3 & 103.4 & 110.6 & 113.4 & 114.4 \\
\hline Real private sector minimum wage & 113.6 & 109.2 & 112.2 & 114.1 & 116.7 & 122.8 \\
\hline \multicolumn{7}{|c|}{ (Percentage change) } \\
\hline \multicolumn{7}{|l|}{ Nominal wage indices } \\
\hline Wages & 14.5 & 19.9 & 23.2 & 18.3 & $\begin{array}{l}10.9 \\
12.4\end{array}$ & 7.1 \\
\hline Private sector minimum wages & 5.0 & 13.8 & 23.9 & 15.0 & 12.4 & 12.6 \\
\hline \multicolumn{7}{|l|}{$\begin{array}{l}\text { Real wage indices } 2 / \\
\text { Wages }\end{array}$} \\
\hline Wages & -2.7 & -0.4 & 4.1 & 7.0 & 2.5 & $\begin{array}{l}0.9 \\
52\end{array}$ \\
\hline Private sector minimum wage & -8.9 & -3.8 & 2.8 & 1.7 & 2.3 & 5.2 \\
\hline \multicolumn{7}{|c|}{ II. Labor Market Indicators, Midyear } \\
\hline \multicolumn{7}{|c|}{ (In percent) } \\
\hline Employment growth & 1.3 & 2.8 & 4.1 & 2.5 & 4.5 & 1.7 \\
\hline Unemployment rate & 9.8 & 9.0 & 9.4 & 8.1 & 8.2 & 7.1 \\
\hline Underemployment rate & 17.5 & 15.9 & 16.9 & 18.2 & 20.7 & 23.0 \\
\hline
\end{tabular}

Sources: Technical Planning Secretariat; Central Bank of Paraguay; and Fund staff estimates.

1/ Refers to greater Asuncion.

2/ Using the consumer price index as the deflator. 
Table 13. Paraguay: Operations of the Consolidated Public Sector

\begin{tabular}{|c|c|c|c|c|c|c|c|}
\hline & 1992 & 1993 & 1994 & 1995 & 1996 & 1997 & $\begin{array}{r}\text { Est. } \\
1998 \\
\end{array}$ \\
\hline \multicolumn{8}{|c|}{ (In billions of guaranies) } \\
\hline Revenue & $1,621.1$ & $1,983.0$ & $2,624.5$ & $3,677.0$ & $3,949.0$ & $4,391.7$ & $4,900.5$ \\
\hline Tax revenue & 921.5 & $1,120.6$ & $1,593.6$ & $2,152.6$ & $2,285.2$ & $2,463.5$ & $2,714.5$ \\
\hline Nontax revenue and grants & 542.7 & 672.2 & 825.9 & $1,032.4$ & $1,212.1$ & $1,389.8$ & $1,605.4$ \\
\hline Public enterprises' operating surplus & 132.8 & 174.4 & 196.8 & 457.0 & 425.6 & 482.5 & 531.0 \\
\hline Capital revenue & 24.1 & 15.7 & 8.3 & 35.0 & 26.1 & 55.9 & 49.6 \\
\hline Current expenditure & $1,268.7$ & $1,467.3$ & $1,886.6$ & $2,298.0$ & $2,741.0$ & $2,994.8$ & $3,573,7$ \\
\hline Wages and salaries & 616.5 & 807.2 & $1,041.2$ & $1,307.5$ & $1,591.3$ & $1,781.3$ & $2,076.8$ \\
\hline Goods and services & 147.6 & 207.3 & 241.8 & 322.4 & 375.7 & 408.4 & 416.2 \\
\hline Interest payments & 126.6 & 93.4 & 100.1 & 129.1 & 96.5 & 101.7 & 196.9 \\
\hline Transfers & 332.5 & 334.1 & 384.9 & 514.8 & 647.8 & 674.6 & 754.6 \\
\hline Other & 45.5 & 25.4 & 118.6 & 24.3 & 29.7 & 28.8 & 129.2 \\
\hline Capital expenditure & 353.4 & 387.5 & 516.8 & 941.9 & 877.6 & $1,565.3$ & $1,615.1$ \\
\hline Current account balance & 352.4 & 515.6 & 737.9 & $1,379.1$ & $1,208.0$ & $1,396.9$ & $1,326.8$ \\
\hline Overall balance & -0.9 & 128.1 & 221.1 & 437.2 & 330.4 & -168.4 & -288.3 \\
\hline Financing & 0.9 & -128.1 & -221.1 & -437.2 & -330.4 & 168.4 & 288.3 \\
\hline External financing & -571.4 & -34.1 & 54.2 & -26.8 & 25.1 & 134.6 & 252.7 \\
\hline Internal financing & 572.3 & -94.0 & -275.3 & -410.4 & -355.6 & 33.8 & 35.6 \\
\hline \multicolumn{8}{|c|}{ (In percent of GDP) } \\
\hline Revenue & 16.8 & 16.5 & 17.5 & 20.8 & 19.8 & 21.0 & 20.8 \\
\hline Tax revenue & 9.5 & 9.3 & 10.7 & 12.2 & 11.5 & 11.8 & 11.5 \\
\hline Nontax revenue and grants & 5.6 & 5.6 & 5.5 & 5.8 & 6.1 & 6.6 & 6.8 \\
\hline Public enterprises' operating surplus & 1.4 & 1.5 & 1.3 & 2.6 & 2.1 & 2.3 & 2.3 \\
\hline Capital revenue & 0.2 & 0.1 & 0.1 & 0.2 & 0.1 & 0.3 & 0.2 \\
\hline Current expenditure & 13.1 & 12.2 & 12.6 & 13.0 & 13.8 & 14.3 & 15.2 \\
\hline Wages and salaries & 6.4 & 6.7 & 7.0 & 7.4 & 8.0 & 8.5 & 8.8 \\
\hline Goods and services & 1.5 & 1.7 & 1.6 & 1.8 & 1.9 & 2.0 & 1.8 \\
\hline Interest payments & 1.3 & 0.8 & 0.7 & 0.7 & 0.5 & 0.5 & 0.8 \\
\hline Transfers & 3.4 & 2.8 & 2.6 & 2.9 & 3.3 & 3.2 & 3.2 \\
\hline Other & 0.5 & 0.2 & 0.8 & 0.1 & 0.1 & 0.1 & 0.5 \\
\hline Capital expenditure & 3.7 & 3.2 & 3.5 & 5.3 & 4.4 & 7.5 & 6.9 \\
\hline Current account balance & 3.6 & 4.3 & 4.9 & 7.8 & 6.1 & 6.7 & 5.6 \\
\hline Overall balance & 0.0 & 1.1 & 1.5 & 2.5 & 1.7 & -0.8 & -1.2 \\
\hline
\end{tabular}

Sources: Ministry of Finance; and Fund staff estimates. 
$-36=$

Table 14. Paraguay: Operations of the Central Government

\begin{tabular}{|c|c|c|c|c|c|c|c|}
\hline & 1992 & 1993 & 1994 & 1995 & 1996 & 1997 & $\begin{array}{r}\text { Est. } \\
1998 \\
\end{array}$ \\
\hline \multicolumn{8}{|c|}{ (In billions of guaranies) } \\
\hline Total Revenue & $1,299.9$ & $1,565.1$ & $2,084.0$ & $2,774.7$ & $2,979.6$ & $3,299.0$ & $3,679.4$ \\
\hline $\begin{array}{l}\text { Tax revenue } \\
\text { Social security contributions }\end{array}$ & 921.5 & $1,120.6$ & $1,593.6$ & $2,152.6$ & $2,285.2$ & $2,463.5$ & $2,714.5$ \\
\hline $\begin{array}{l}\text { Social security contributions } \\
\text { Income taxes }\end{array}$ & 71.3 & 104.3 & 133.9 & 171.5 & 210.8 & 227.3 & 258.1 \\
\hline $\begin{array}{l}\text { Income taxes } \\
\text { Taxes on goods and services }\end{array}$ & 128.0 & 174.5 & 298.5 & 399.5 & 440.9 & 428.7 & 449.7 \\
\hline $\begin{array}{l}\text { Taxes on goods and services } \\
\text { General sales tax }\end{array}$ & 562.7 & 637.8 & 870.5 & $1,089.1$ & $1,189.4$ & $1,325.6$ & $1,463.7$ \\
\hline & 174.0 & 131.0 & 171.5 & 212.0 & 275.7 & 272.6 & 279.6 \\
\hline $\begin{array}{l}\text { Value added tax } \\
\text { Stamp tax }\end{array}$ & $\begin{array}{l}130.1 \\
136.6\end{array}$ & 410.0 & 595.3 & 772.3 & 814.3 & 951.3 & $1,074.8$ \\
\hline $\begin{array}{l}\text { Stamp tax } \\
\text { Other }\end{array}$ & $\begin{array}{l}136.6 \\
122.1\end{array}$ & 65.2 & 74.3 & 64.9 & & 75.1 & 84.4 \\
\hline Taxes on international transactions & $\begin{array}{l}122.1 \\
159.5\end{array}$ & $\begin{array}{r}31.6 \\
204.0\end{array}$ & 29.4 & 39.8 & $\begin{array}{r}31.0 \\
444.1\end{array}$ & $\begin{array}{r}26.6 \\
481.8\end{array}$ & 25.0 \\
\hline Import duties & 159.4 & $\begin{array}{l}204.0 \\
204.0\end{array}$ & 290.6 & $\begin{array}{l}492.6 \\
492.6\end{array}$ & $\begin{array}{l}444.1 \\
444.1\end{array}$ & $\begin{array}{l}481.8 \\
481.8\end{array}$ & 543.0 \\
\hline Other & 0.1 & $\begin{array}{r}204.0 \\
0.0\end{array}$ & $\begin{array}{r}290.6 \\
0.0\end{array}$ & $\begin{array}{r}492.0 \\
0.0\end{array}$ & 0.0 & $\begin{array}{r}481.8 \\
0.0\end{array}$ & $\begin{array}{r}543.0 \\
0.0\end{array}$ \\
\hline Nontax revenue & 371.7 & 437.1 & 482.5 & 591.6 & 668.6 & 0.0 & 0.0 \\
\hline Itaipu & 231.4 & 283.3 & 326.2 & 346.0 & $\begin{array}{l}668.6 \\
369.3\end{array}$ & 792.8 & 918.9 \\
\hline Other (incl. grants) & 140.4 & 153.9 & 156.4 & 245.6 & 299.3 & 528.8 & 669.3 \\
\hline Capital revenue & 6.6 & 7.3 & & 30.5 & & 264.0 & 249.6 \\
\hline Current expenditures & & & 17057 & & 25.8 & 42.7 & 46.1 \\
\hline Wages and salaries & $\begin{array}{r}1,149.7 \\
534.9\end{array}$ & $\begin{array}{r}1,334.3 \\
713.4\end{array}$ & $\begin{array}{r}1,705.7 \\
923.7\end{array}$ & $\begin{array}{l}2,062.7 \\
1,149.7\end{array}$ & $2,449.3$ & $2,665.0$ & $3,147.5$ \\
\hline Goods and services & 122.7 & 173.3 & $\begin{array}{l}923.7 \\
191.8\end{array}$ & $\begin{array}{r}1,149.7 \\
257.1\end{array}$ & $\begin{array}{r}1,386.4 \\
300.0\end{array}$ & $1,551.1$ & $1,780.3$ \\
\hline Interest payments & 126.5 & 93.0 & 100.0 & 127.9 & 300.0 & 307.5 & 313.1 \\
\hline Transfers & 321.2 & 333.6 & 385.5 & 511.4 & $\begin{array}{r}96.5 \\
644.5\end{array}$ & 101.7 & 196.9 \\
\hline Other & 44.5 & 21.0 & 104.8 & 16.6 & $\begin{array}{r}644.5 \\
22.0\end{array}$ & 686.6 & 737.0 \\
\hline Capital expenditures & & & & & & 18.1 & 120.2 \\
\hline Capital formation & $\begin{array}{l}243.1 \\
146.2\end{array}$ & $\begin{array}{l}230.9 \\
166.1\end{array}$ & $\begin{array}{l}359.5 \\
262.6\end{array}$ & $\begin{array}{l}762.3 \\
564.6\end{array}$ & $\begin{array}{l}685.0 \\
532.8\end{array}$ & $\begin{array}{l}936.5 \\
747.8\end{array}$ & $\begin{array}{l}881.3 \\
755.2\end{array}$ \\
\hline $\begin{array}{l}\text { Capital transfers } \\
\text { Other }\end{array}$ & 96.9 & 64.8 & 96.9 & 171.2 & 132.9 & 140.3 & $\begin{array}{l}123.2 \\
126.1\end{array}$ \\
\hline Other & 0.0 & 0.0 & 0.0 & 26.4 & 19.3 & 48.4 & 0.0 \\
\hline Culrent account balance & 150.1 & 230.9 & 378.3 & 712.0 & 530.3 & 634.0 & 531.9 \\
\hline Overall balance & -92.9 & -0.1 & 18.9 & -50.2 & -154.7 & -302.5 & -349.4 \\
\hline Financing & 92.9 & 0.1 & -18.9 & 50.2 & 154.7 & 302.5 & 349.4 \\
\hline External financing & -154.2 & -100.1 & 19.1 & 118.6 & 67.8 & 147.0 & -9.4 \\
\hline Internal financing & 247.1 & 100.1 & -37.9 & -68.4 & 86.9 & 155.5 & 358.8 \\
\hline \multicolumn{8}{|c|}{ (In percent of GDP) } \\
\hline $\begin{array}{l}\text { Total Revenue } \\
\text { Tax revenue }\end{array}$ & $\begin{array}{r}13.4 \\
9.5\end{array}$ & $\begin{aligned} 13.1 \\
9.3\end{aligned}$ & $\begin{array}{l}13.9 \\
10.7\end{array}$ & $\begin{array}{l}15.7 \\
12.2\end{array}$ & $\begin{array}{l}15.0 \\
11.5\end{array}$ & $\begin{array}{l}15.8 \\
11.8\end{array}$ & $\begin{array}{l}15.6 \\
11.5\end{array}$ \\
\hline $\begin{array}{l}\text { Tax revenue } \\
\text { Social security contributions }\end{array}$ & $\begin{array}{l}9.5 \\
0.7\end{array}$ & $\begin{array}{l}9.3 \\
0.9\end{array}$ & $\begin{array}{r}0.1 \\
0.9\end{array}$ & $\begin{array}{r}1.2 \\
1.0\end{array}$ & 1.1 & 1.1 & $\begin{array}{r}11.5 \\
1.1\end{array}$ \\
\hline Income taxes & 1.3 & 1.5 & 2.0 & 2.3 & 2.2 & 2.0 & $\begin{array}{l}1.1 \\
1.9\end{array}$ \\
\hline Taxes on goods and services & 5.8 & 5.3 & 5.8 & 6.2 & 6.0 & 6.3 & $\begin{array}{l}1.9 \\
6.2\end{array}$ \\
\hline Taxes on international transactions & 1.6 & 1.7 & 1.9 & 2.8 & 2.2 . & 2.3 & 2.3 \\
\hline Nontax revenue & 3.8 & 3.6 & 3.2 & 3.3 & 3.4 & 3.8 & 3.9 \\
\hline Itaipu & 2.4 & 2.4 & 2.2 & 2.0 & 1.9 & 2.5 & 2.8 \\
\hline Other (including grants) & 1.5 & 1.3 & 1.0 & 1.4 & 1.5 & 1.3 & 1.1 \\
\hline Capital revenue & 0.1 & 0.1 & 0.1 & 0.2 & 0.1 & 0.2 & 0.2 \\
\hline Current expenditures & 11.9 & 11.1 & 11.4 & 11.7 & 12,3 & 12.7 & 13.4 \\
\hline $\begin{array}{l}\text { Wages and salaries } \\
\text { Goods and services }\end{array}$ & 5.5 & 5.9 & 6.2 & 6.5 & 7.0 & 7.4 & 7.6 \\
\hline Goods and services & 1.3 & 1.4 & 1.3 & 1.5 & 1.5 & 1.5 & 1.3 \\
\hline Interest payments & 1.3 & 0.8 & 0.7 & 0.7 & 0.5 & 0.5 & 0.8 \\
\hline Transfers & 3.3 & 2.8 & 2.6 & 2.9 & 3.2 & 3.3 & 3.1 \\
\hline Other & 0.5 & 0.2 & 0.7 & 0.1 & 0.1 & 0.1 & 0.5 \\
\hline Capital expenditures & 2.5 & 1.9 & 2.4 & 4.3 & 3.4 & 4.5 & 3.7 \\
\hline Current account balance & 1.6 & 1.9 & 2.5 & 4.0 & 2.7 & 3.0 & 23 \\
\hline Overall balance & -1.0 & 0.0 & 0.1 & -0.3 & -0.8 & -1.4 & -1.5 \\
\hline Financing & 1.0 & 0.0 & -0.1 & 0.3 & 0.8 & 1.4 & 1.5 \\
\hline $\begin{array}{l}\text { External financing } \\
\text { Internal financing }\end{array}$ & -1.6 & -0.8 & 0.1 & 0.7 & 0.3 & 0.7 & 0.0 \\
\hline Internal financing & 2.6 & 0.8 & -0.3 & -0.4 & 0.4 & 0.7 & 1.5 \\
\hline
\end{tabular}

Sources: Ministry of Finance; and Fund staff estimates. 
Table 15. Paraguay: Operations of IPS

\begin{tabular}{|c|c|c|c|c|c|c|c|}
\hline & 1992 & 1993 & 1994 & 1995 & 1996 & 1997 & $\begin{array}{r}\text { Est. } \\
1998 \\
\end{array}$ \\
\hline \multicolumn{8}{|c|}{ (In billions of guaranies) } \\
\hline Revenues & 166.3 & 229.7 & 334.4 & 428.3 & 527.8 & 588.3 & 671.0 \\
\hline Social security contributions & 155.6 & 193.3 & 268.0 & 332.0 & 388.0 & 434.6 & 491.2 \\
\hline Current transfers from central government & 0.0 & 0.0 & 0.0 & 0.0 & 0.0 & 0.0 & 0.0 \\
\hline Other current revenue & 10.1 & 33.9 & 66.4 & 96.3 & 139.8 & 150.9 & 176.8 \\
\hline Capital revenue & 0.6 & 2.6 & 0.0 & 0.0 & 0.0 & 2.8 & 3.0 \\
\hline Current expenditures & 100.7 & 129.0 & 172.7 & 223.6 & 278.5 & 321.0 & 415.6 \\
\hline Wages and salaries & 32.3 & 47.3 & 57.7 & 80.0 & 108.6 & 125.3 & 188.5 \\
\hline Goods and services & 19.0 & 26.4 & 35.7 & 49.6 & 56.6 & 81.3 & 84.3 \\
\hline Interest payments & 0.0 & 0.0 & 0.0 & 0.0 & 0.0 & 0.0 & 0.0 \\
\hline Transfers & 49.0 & 52.5 & 67.7 & 88.5 & 108.3 & 106.3 & 136.1 \\
\hline Other & 0.4 & 2.9 & 11.6 & 5.4 & 5.0 & 8.1 & 6.6 \\
\hline Capital expenditures & 6.8 & 3.4 & 3.7 & 12.0 & 10.4 & 137.4 & 145.6 \\
\hline Current account balance & 65.5 & 100.7 & 161.7 & 204.7 & 249.3 & 267.3 & 255.4 \\
\hline Overall balance & 58.8 & 97.3 & 158.0 & 192.7 & 238.9 & 129.9 & 109.8 \\
\hline Financing & -58.8 & -97.3 & -158.0 & -192.7 & -238.9 & -129.9 & -109.8 \\
\hline External financing & 0.0 & 0.0 & 0.0 & 0.0 & 0.0 & 0.0 & 0.0 \\
\hline Internal financing & -58.8 & -97.3 & -158.0 & -192.7 & -238.9 & -129.9 & -109.8 \\
\hline \multicolumn{8}{|c|}{ (In percent of GDP) } \\
\hline Revenues & 1.7 & 1.9 & 2.2 & 2.4 & 2.7 & 2.8 & 2.8 \\
\hline Current expenditure & 1.0 & 1.1 & 1.2 & 1.3 & 1.4 & 1.5 & 1.8 \\
\hline Wages and salaries & 0.3 & 0.4 & 0.4 & 0.5 & 0.5 & 0.6 & 0.8 \\
\hline Goods and services & 0.2 & 0.2 & 0.2 & 0.3 & 0.3 & 0.4 & 0.4 \\
\hline Interest payments & 0.0 & 0.0 & 0.0 & 0.0 & 0.0 & 0.0 & 0.0 \\
\hline Transfers & 0.5 & 0.4 & 0.5 & 0.5 & 0.5 & 0.5 & 0.6 \\
\hline Other & 0.0 & 0.0 & 0.1 & 0.0 & 0.0 & 0.0 & 0.0 \\
\hline Capital expenditure & 0.1 & 0.0 & 0.0 & 0.1 & 0.1 & 0.7 & 0.6 \\
\hline Current account balance & 0.7 & 0.8 & 1.1 & 1.2 & 1.3 & 1.3 & 1.1 \\
\hline Overall balance & 0.6 & 0.8 & 1.1 & 1.1 & 1.2 & 0.6 & 0.5 \\
\hline Financing & -0.6 & -0.8 & -1.1 & -1.1 & -1.2 & -0.6 & -0.5 \\
\hline External financing & 0.0 & 0.0 & 0.0 & 0.0 & 0.0 & 0.0 & 0.0 \\
\hline Internal financing & -0.6 & .0 .8 & -1.1 & -1.1 & -1.2 & $-0.6^{\circ}$ & -0.5 \\
\hline
\end{tabular}

Sources: Ministry of Finance; and Fund staff estimates. 
Table 16. Paraguay: Rest of General Government (IBR, UNA)

\begin{tabular}{|c|c|c|c|c|c|c|c|}
\hline & 1992 & 1993 & 1994 & 1995 & 1996 & 1997 & $\begin{array}{r}\text { Est. } \\
1998 \\
\end{array}$ \\
\hline \multicolumn{8}{|c|}{ (In billions of guaranies) } \\
\hline Revenues & 55.2 & 66.7 & 96.3 & 141.0 & 169.0 & 155.9 & 173.6 \\
\hline Current transfers from central government & 34.7 & 46.8 & 64.1 & 80.2 & 99.4 & 111.7 & 113.3 \\
\hline Other current revenues & 8.3 & 11.9 & 13.9 & 18.4 & 22.7 & 21.8 & 29.8 \\
\hline Capital revenues & 12.2 & 8.0 & 18.3 & 42.4 & 46.9 & 22.4 & 30.5 \\
\hline Current expenditures & 55.9 & 56.0 & 76.5 & 96.9 & 118.2 & 128.4 & 132.6 \\
\hline Wages and salaries & 49.3 & 46.6 & 59.9 & 77.8 & 96.4 & 104.9 & 107.9 \\
\hline Goods and services & 6.0 & 7.5 & 14.2 & 15.7 & 19.1 & 19.6 & 18.9 \\
\hline Interest payments & 0.1 & 0.4 & 0.1 & 1.2 & 0.0 & 0.0 & 0.0 \\
\hline Transfers & 0.0 & 0.0 & 0.0 & 0.0 & 0.0 & 1.2 & 3.5 \\
\hline Other & 0.6 & 1.5 & 2.2 & 2.3 & 2.7 & 2.6 & 2.4 \\
\hline Capital expenditures & 15.3 & 6.6 & 17.3 & 45.7 & 23.1 & 22.4 & 36.7 \\
\hline Current account balance & -0.7 & 10.7 & 19.8 & 44.1 & 50.8 & 27.5 & 40.9 \\
\hline Overall balance & -16.0 & 4.1 & 2.5 & -1.6 & 27.7 & 5.1 & 4.3 \\
\hline Financing & 16.0 & -4.1 & -2.5 & 1.6 & -27.7 & -5.1 & -4.3 \\
\hline External financing & 0.0 & 0.0 & 0.0 & 0.0 & -0.3 & 0.0 & 0.0 \\
\hline Internal financing & 16.0 & -4.1 & -2.5 & 1.6 & -27.4 & -5.1 & -4.3 \\
\hline
\end{tabular}

Source: Ministry of Finance; and Fund staff estimates. 
$-39$.

Table 17. Paraguay: Operations of the Public Enterprises

\begin{tabular}{|c|c|c|c|c|c|c|c|}
\hline & 1992 & 1993 & 1994 & 1995 & 1996 & 1997 & $\begin{array}{r}\text { Est. } \\
1998 \\
\end{array}$ \\
\hline \multicolumn{8}{|c|}{ (In billions of guaranies) } \\
\hline Revenues & 944.6 & $1,163.6$ & $1,270.4$ & $1,537,6$ & $1,711.6$ & $1,994.2$ & $2,276.9$ \\
\hline Sales of goods and services & 920.0 & $1,152.6$ & $1,257.8$ & $1,524.3$ & $1,704.7$ & $1,977.4$ & $2,269.1$ \\
\hline Current transfers from central government & 3.0 & 5.2 & 4.1 & 5.0 & 5.7 & 5.4 & 6.4 \\
\hline Capital revenue & 21.5 & 5.8 & 8.5 & 8.4 & 1.1 & 11.4 & 1.4 \\
\hline Current expenditures & 790.2 & 982.1 & $1,065.9$ & $1,073.2$ & $1,286.1$ & $1,502.8$ & $1,747.0$ \\
\hline Wages and salaries & 157.4 & 181.8 & 214.3 & 250.8 & 301.5 & 408.6 & 459.6 \\
\hline Goods and services & 440.5 & 651.1 & 634.3 & 631.8 & 799.0 & 927.5 & $1,122.5$ \\
\hline Interest payments & 85.2 & 34.0 & 49.4 & 35.1 & 34.4 & 25.2 & 26.4 \\
\hline Transfers & 39.1 & 75.3 & 109.1 & 134.7 & 138.7 & 11.2 & 17.0 \\
\hline Other & 68.0 & 39.8 & 58.9 & 20.8 & 12.4 & 130.4 & 121.5 \\
\hline Capital expenditures & 105.2 & 154.7 & 162.7 & 168.1 & 206.9 & 492.3 & 582.8 \\
\hline Current account balance & 154.4 & 181.4 & 204.5 & 464.4 & 425.5 & 491.4 & 529.9 \\
\hline Overall balance & 49.2 & 26.8 & 41.8 & 296.3 & 218.6 & -1.0 & -52.9 \\
\hline Financing & -49.2 & -26.8 & -41.8 & -296.3 & -218.6 & 1.0 & 52.9 \\
\hline External financing & -417.2 & 66.0 & 35.1 & -145.5 & -42.4 & -12.4 & 262.1 \\
\hline Internal financing & 368.0 & -92.8 & -76.9 & -150.8 & -176.2 & 13.3 & -209.2 \\
\hline \multicolumn{8}{|c|}{ (In percent of GDP) } \\
\hline Revenues & 9.8 & 9.7 & 8.5 & 8.7 & 8.6 & 9.5 & 9.7 \\
\hline Current expenditures & 8.2 & 8.2 & 7.1 & 6.1 & 6.5 & 7.2 & 7.4 \\
\hline Wages and salaries & 1.6 & 1.5 & 1.4 & 1.4 & 1.5 & 2.0 & 1.9 \\
\hline Goods and services & 4.6 & 5.4 & 4.2 & 3.6 & 4.0 & 4.4 & 4.8 \\
\hline Interest payments & 0.9 & 0.3 & 0.3 & 0.2 & 0.2 & 0.1 & 0.1 \\
\hline Transfers & 0.4 & 0.6 & 0.7 & 0.8 & 0.7 & 0.1 & 0.1 \\
\hline Other & 0.7 & 0.3 & 0.4 & 0.1 & 0.1 & 0.6 & 0.5 \\
\hline Capital expenditures & 1.1 & 1.3 & 1.1 & 0.9 & 1.0 & 2.4 & 2.5 \\
\hline Current account balance & 1.6 & 1.5 & 1.4 & 2.6 & 2.1 & .2 .3 & 2.2 \\
\hline Overall balance & 0.5 & 0.2 & 0.3 & 1.7 & 1.1 & 0.0 & -0.2 \\
\hline Financing & -0.5 & -0.2 & -0.3 & -1.7 & -1.1 & 0.0 & 0.2 \\
\hline External financing & -4.3 & 0.6 & 0.2 & -0.8 & -0.2 & -0.1 & 1.1 \\
\hline Internal financing & 3.8 & -0.8 & -0.5 & -0.9 & -0.9 & 0.1 & -0.9 \\
\hline
\end{tabular}

Sources: Ministry of Finance; and Fund staff estimates. 
Table 18. Paraguay: Accounts of the Financial System

(In billions of guaranies)

\begin{tabular}{|c|c|c|c|c|c|c|}
\hline & 1992 & 1993 & 1994 & 1995 & 1996 & 1997 \\
\hline \multicolumn{7}{|c|}{ I. Financial System } \\
\hline Net foreign assets & $1,296.3$ & $1,664.4$ & $2,355.2$ & $2,329.6$ & $2,628.3$ & $2,120.7$ \\
\hline Assets & $1,374.8$ & $1,831.3$ & $2,582.7$ & $3,172.2$ & $3,069.4$ & $2,758.7$ \\
\hline Liabilities & 78.6 & 167.0 & 227.5 & 842.6 & 441.0 & 638.0 \\
\hline Net domestic assets & $2,285.4$ & $2,877.0$ & $3,333.1$ & $4,526.2$ & $5,408.0$ & $7,255.8$ \\
\hline Net claims on public sector & 486.2 & 542.3 & 92.5 & -246.2 & -504.7 & 85.4 \\
\hline General government & 398.0 & 437.7 & 11.6 & -282.4 & -479.3 & -29.8 \\
\hline Rest of the public sector & 88.2 & 104.6 & 80.9 & 36.2 & -25.4 & 115.2 \\
\hline Credit to nonfinancial private sector & $2,151.2$ & $2,921,8$ & $4,029.9$ & $4,801.5$ & $5,843.0$ & $6,726.8$ \\
\hline o.w. foreign currency & 346.0 & 580.9 & 949.8 & $1,284.6$ & $1,611.2$ & $2,329.1$ \\
\hline Net unclassified assets & -351.9 & -587.1 & -789.4 & -29.1 & 69.7 & 443.6 \\
\hline Net intra-financial float & 5.1 & -30.7 & -73.2 & -131.7 & 0.8 & -33.8 \\
\hline Medium \& long term external liabilities & -233.2 & -286.8 & -189.0 & -208.2 & -208.0 & -167.7 \\
\hline Capital and reserves & -863.4 & $-1,060.2$ & $-1,473.7$ & $-1,820.8$ & $-2,162.0$ & $-2,798.5$ \\
\hline Official & -513.7 & -548.2 & -663.1 & -831.3 & -945.7 & $-1,392.1$ \\
\hline Private & -349.7 & -512.0 & -810.6 & -989.5 & $-1,216.3$ & $-1,406.4$ \\
\hline Liabilities to private sector & $2,500.1$ & $3,171.1$ & $3,964.6$ & $4,720.7$ & $5,690.5$ & $6,399.0$ \\
\hline Currency in circulation. & 531.3 & 635.8 & 800.5 & 956.0 & 961.8 & $1,122.9$ \\
\hline Local currency deposits & $1,004.9$ & $1,130.1$ & $1,636.7$ & $2,208.5$ & $2,661.2$ & $2,853.4$ \\
\hline Demand deposits & 272.3 & 324.9 & 472.1 & 583.4 & 608.9 & 666.2 \\
\hline Time and savings deposits & 558.2 & 623.9 & 953.0 & $1,211.9$ & $1,529.6$ & $1,582.0$ \\
\hline Certificates of deposit & 174.4 & 181.2 & 211.6 & 413.2 & 522.6 & 605.2 \\
\hline Foreign currency deposits & 756.1 & $1,156.6$ & $1,333.8$ & $1,375.2$ & $1,926.7$ & $2,421.6$ \\
\hline Trust funds $1 /$ & 207.8 & 248.7 & 193.6 & 180.9 & 140.9 & 1.0 \\
\hline
\end{tabular}


Table 18. Paraguay: Accounts of the Financial System (continued)

(In billions of guaraníes)

\begin{tabular}{|c|c|c|c|c|c|c|}
\hline & 1992 & 1993 & 1994 & 1995 & 1996 & 1997 \\
\hline \multicolumn{7}{|c|}{ II. Central Bank } \\
\hline Net international reserves & 979.3 & $1,264.3$ & $1,992.7$ & $2,189.7$ & $2,233.7$ & $1,967.4$ \\
\hline Assets & 986.7 & $1,281.6$ & $2,008.9$ & $2,320.8$ & $2,323.4$ & $2,085.5$ \\
\hline Liabilities & 7.5 & 17.4 & 16.2 & 131.1 & 89.8 & 118.0 \\
\hline Net domestic assets & 369.1 & 425.1 & 133.7 & -220.9 & -326.2 & 855.2 \\
\hline Net claims on public sector & 729.8 & 957.6 & 797.4 & 615.6 & 669.1 & 995.7 \\
\hline General government & 566.5 & 782.4 & 632.9 & 464.6 & 519.4 & 730.6 \\
\hline Rest of the public sector & 163.3 & 175.2 & 164.5 & 151.0 & 149.6 & 265.2 \\
\hline Net credit to the private sector & -3.8 & -10.8 & -19.9 & -18.8 & -39.9 & -39.8 \\
\hline Net unclassified assets & -357.0 & -521.7 & -643.8 & -817.7 & -955.3 & -100.7 \\
\hline Medium \& long term external liabilities & -92.1 & -98.3 & -97.0 & -93.5 & -92.4 & -94.4 \\
\hline Net position with fin. intermediaries & -391.6 & -597.0 & -920.8 & -634.7 & -575.3 & -388.5 \\
\hline Credit to banks & 170.3 & 102.8 & 98.1 & 761.7 & 926.1 & $1,211.6$ \\
\hline Credit to rest of fin. System & 16.5 & 16.2 & 15.6 & 44.4 & 128.0 & 200.8 \\
\hline Deposits from commercial banks & -540.7 & -673.8 & -863.0 & -967.7 & $-1,064.1$ & $-1,125.5$ \\
\hline Deposits from rest of financial system & -37.7 & -25.6 & -42.7 & -94.8 & .76 .1 & -69.8 \\
\hline Bank and BNF holdings of LRM & 0.0 & -8.6 & -93.3 & -171.6 & -230.3 & -270.4 \\
\hline Rest of FS holdings (-) of LRM or LRM float (+) & 0.0 & 0.6 & 57.8 & -35.1 & -28.7 & -64.9 \\
\hline Bank vault cash & 0.0 & -8.6 & -93.3 & -171.6 & -230.3 & -270.4 \\
\hline Capital and reserves & -286.9 & -304.1 & -331.9 & -376.5 & -376.0 & $-1,356.5$ \\
\hline Official & -286.9 & -304.1 & -331.9 & -376.5 & -376.0 & $-1,356.5$ \\
\hline Private & 0.0 & 0.0 & 0.0 & 0.0 & 0.0 & 0.0 \\
\hline Private sector currency holdings & 577.7 & 689.9 & 776.8 & 864.1 & 863.8 & 983.3 \\
\hline
\end{tabular}


Table 18. Paraguay: Accounts of the Financial System (continued)

(In billions of guaranies)

\begin{tabular}{|c|c|c|c|c|c|c|}
\hline & 1992 & 1993 & 1994 & 1995 & 1996 & 1997 \\
\hline \multicolumn{7}{|c|}{ III. Commercial Banks } \\
\hline Net foreign assets & 317.0 & 400.1 & 362.5 & 139.3 & 393.3 & 137.3 \\
\hline Assets & 388.1 & 549.7 & 573.7 & 850.7 & 744.5 & 657.2 \\
\hline Liabilities & 71.1 & 149.6 & 211.3 & 711.5 & 351.3 & 519.9 \\
\hline Net domestic assets & $1,463.0$ & $1,876.9$ & $2,407.6$ & $3,089.2$ & $3,909.9$ & $4,647.2$ \\
\hline Net claims on public sector & -243.6 & -415.3 & -704.9 & -861.7 & $-1,173.8$ & -910.4 \\
\hline General government & -168.5 & -344.6 & -621.3 & -747.0 & -998.8 & -760.4 \\
\hline Rest of the public sector & -75.1 & -70.7 & -83.6 & -114.8 & -175.1 & -150.0 \\
\hline Credit to private sector & $1,712.9$ & $2,315.4$ & $3,164.9$ & $3,742.7$ & $4,596.5$ & $5,166.0$ \\
\hline Of which: foreign currency & 346.0 & 580.9 & 949.8 & $1,284.6$ & $1,611.2$ & $2,329.1$ \\
\hline Net unclassified assets & -6.2 & -23.1 & -52.4 & 208.2 & 487.2 & 391.6 \\
\hline Medium \& long term external liabilities & -73.0 & -120.1 & -28.4 & -53.8 & -50.0 & -5.6 \\
\hline Net position with rest of fin. system & 421.1 & 660.3 & 866.4 & $1,091.1$ & $1,079.6$ & $1,185.7$ \\
\hline Vault cash & 4.4 & & & & & \\
\hline Credit to (deposits in) Central Bank & 588.2 & 744.0 & 855.5 & $1,029.9$ & $1,169.0$ & $1,184.1$ \\
\hline Deposits (credit) from Central Bank & 169.2 & 102.4 & 94.0 & 156.4 & 346.6 & 321.6 \\
\hline LRMs held by banks & 0.0 & 8.6 & 93.3 & 171.6 & 230.3 & 270.4 \\
\hline Credit to (deposits in) rest of financial system & 4.9 & 11.1 & 11.6 & 54.3 & 28.6 & 52.9 \\
\hline Deposits (credit) from rest. of fin. system & 2.8 & 0.9 & 0.0 & 8.4 & 1.7 & 0.0 \\
\hline Capital and reserves & -342.2 & -483.0 & -719.5 & -839.8 & $-1,032.0$ & $-1,237.8$ \\
\hline Official & -50.6 & -54.3 & .75 .1 & -84.7 & -95.6 & -112.7 \\
\hline Private & -291.6 & -428.7 & -644.4 & -755.1 & -936.4 & $-1,125.1$ \\
\hline Liabilities to private sector & $1,789.2$ & $2,334.3$ & $2,893.1$ & $3,426.0$ & $4,300.7$ & $4,726.9$ \\
\hline Local currency deposits & 825.3 & 929.0 & $1,365.7$ & $1,871.3$ & $2,243.0$ & $2,314.5$ \\
\hline Demand deposits & 272.3 & 324.9 & 472.1 & 583.4 & 608.9 & 666.2 \\
\hline Time and savings deposits & 404.1 & 432.1 & 688.0 & 891.4 & $1,172.3$ & $1,185.5$ \\
\hline Certificates of deposit & 148.9 & 171.9 & 205.6 & 396.5 & 461.7 & 462.8 \\
\hline Foreign currency deposits & 756.1 & $1,156.6$ & $1,333.8$ & $1,373.7$ & $1,916.9$ & $2,411.3$ \\
\hline Trust funds & 207.8 & 248.7 & 193.6 & 180.9 & 140.9 & 1.0 \\
\hline
\end{tabular}


Table 18. Paraguay: Accounts of the Financial System (concluded)

(In billions of guaranies)

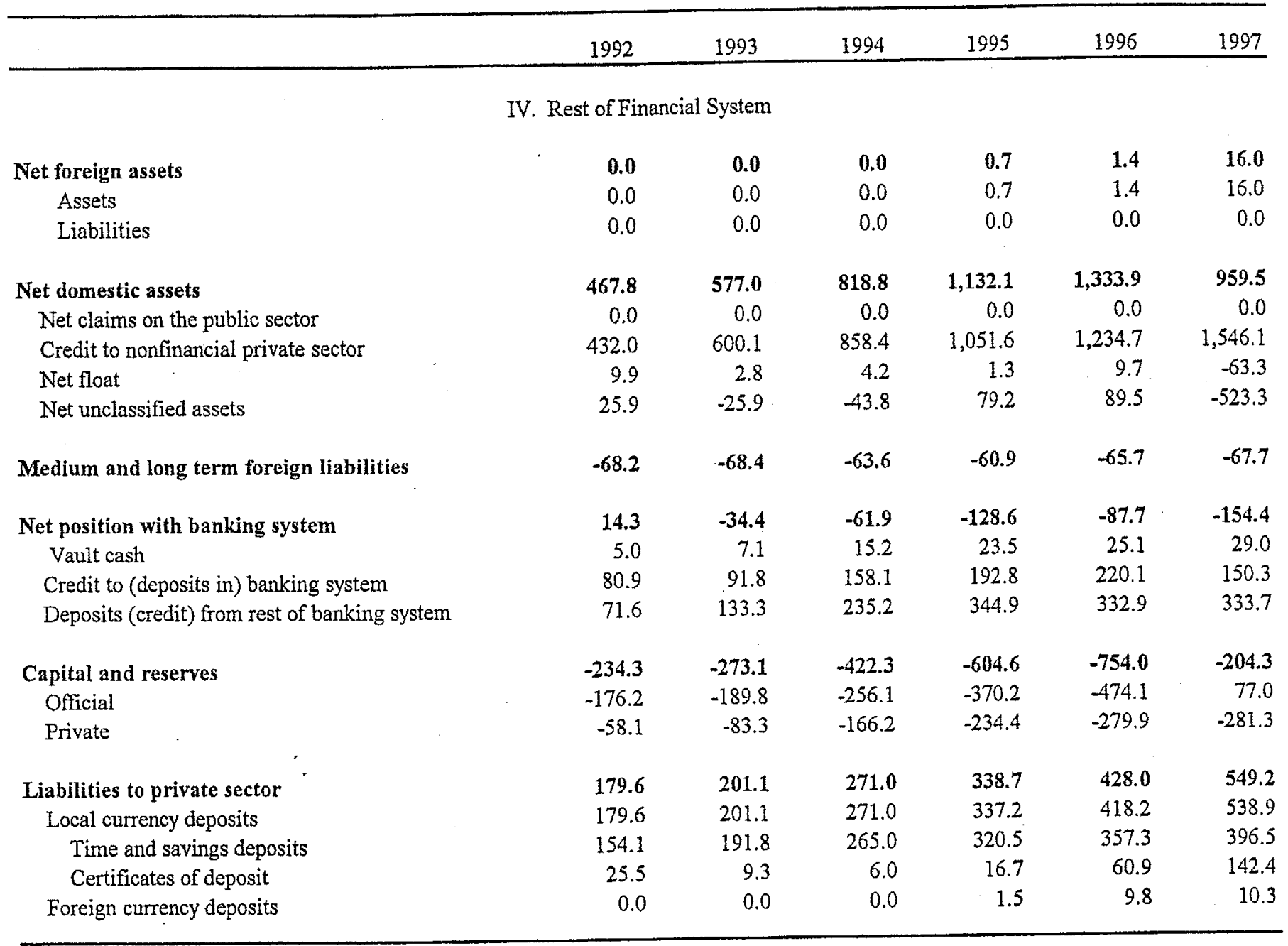

Source: Central Bank of Paraguay.

1/ Letras de regulacion.

$2 /$ Includes bond placements. 
Table 19. Paraguay: Costs of Banking Rescue Operations 1/

(In billions of guaranies)

\begin{tabular}{|c|c|c|c|c|c|c|}
\hline & 1995 & 1996 & 1997 & 1998 & 199921 & Total \\
\hline $\mathrm{BCP}$ resources & 704 & 0 & 236 & 396 & 0 & 1,335 \\
\hline Loans to banks & 618 & 0 & 158 & 213 & 0 & 989 \\
\hline Losses on bonds $(a-b)$ & 0 & 0 & 78 & 168 & 0 & 246 \\
\hline a. Face value & 0 & 0 & 113 & 230 & 0 & 343 \\
\hline b. Present value & 0 & 0 & 35 & 62 & 0 & 97 \\
\hline Loans to finance houses & 86 & 0 & 0 & 15 & 0 & 101 \\
\hline Deposit restitution 3/ & 0 & 0 & 0 & 65 & 672 & 737 \\
\hline Total BCP costs & 704 & 0 & 236 & 461 & 672 & 2,073 \\
\hline Public enterprises & 0 & 0 & 0 & 0 & 787 & 787 \\
\hline Grand total & 704 & 0 & 236 & 461 & 1,459 & 2,859 \\
\hline (in US\$ million) & 358 & 0 & 108 & 171 & 430 & 1,068 \\
\hline \multicolumn{7}{|l|}{ Memorandum item } \\
\hline & & & & & & \\
\hline
\end{tabular}

Sources: Central Bank of Paraguay, Superintendent of Banks; and Fund staff estimates.

1/ Based on Sept/98 figures; the total is a likely maximum. Costs may be lower if assets are recuperated in liquidated banks.

2/ 1999 and beyond.

3/ 100 minimum wages. 
Table 20. Paraguay: Banking System - Distribution of Credit to the Private Sector $1 / 2 /$

\begin{tabular}{|c|c|c|c|c|c|c|}
\hline & 1992 & 1993 & 1994 & 1995 & 1996 & 1997 \\
\hline \multicolumn{7}{|c|}{ (In billions of guaranies) } \\
\hline Total credit & $1,483.8$ & $1,996.4$ & $2,802.8$ & $3,502.8$ & $4,302.1$ & $5,222.4$ \\
\hline National Development Bank & 284.9 & 339.9 & 413.3 & 504.4 & 608.5 & $1,265.5$ \\
\hline Agriculture & 229.9 & 259.7 & 276.9 & $\ldots$ & 357.8 & 435.3 \\
\hline Cattle & 5.9 & 13.0 & 24.4 & $\ldots$ & 43.5 & ... \\
\hline Industry & 38.1 & 51.3 & 68.8 & $\ldots$ & 134,4 & 242.8 \\
\hline Commerce & 8.7 & 8.3 & 12.3 & $\ldots$ & 35.4 & 255.8 \\
\hline Exports & 0.9 & 5.6 & 28.8 & $\ldots$ & 34.7 & 19.7 \\
\hline Other & 1.4 & 2.0 & 2.1 & $\ldots$ & 2.7 & 311.9 \\
\hline Commercial banks & $1,198.9$ & $1,656.5$ & $2,389.5$ & $2,998.4$ & $3,693.6$ & $3,956.9$ \\
\hline Agriculture & 165.1 & 216.6 & 235.2 & $\ldots$ & 218.3 & 229.7 \\
\hline Cattle & 44.4 & 49.4 & 80.5 & $\ldots$ & 129.5 & 69.4 \\
\hline Industry & 115.6 & 146.6 & 192.6 & $\ldots$ & 409.0 & 487.7 \\
\hline Commerce & 533.4 & 828.6 & $1,360.5$ & $\ldots$ & $1,847.0$ & $1,742.3$ \\
\hline Exports & 156.7 & 205.9 & 211.7 & $\ldots$ & 154.5 & 154.1 \\
\hline Other & 183.7 & 209.4 & 309.0 & $\ldots$ & 935.3 & $1,273.7$ \\
\hline \multicolumn{7}{|c|}{ (In percent) } \\
\hline Total credit & 100.0 & 100.0 & 100.0 & 100.0 & 100.0 & 100.0 \\
\hline National Development Bank & 19.2 & 17.0 & 14.7 & 14.4 & 14.1 & 24.2 \\
\hline Agriculture & 15.5 & 13.0 & 9.9 & $\ldots$ & 8.3 & 8.3 \\
\hline Cattle & 0.4 & 0.7 & 0.9 & $\cdots$ & 1.0 & $\ldots$ \\
\hline Industry & 2.6 & 2.6 & 2.5 & $\ldots$ & 3.1 & 4.6 \\
\hline Commerce & 0.6 & 0.4 & 0.4 & $\ldots$ & 0.8 & 4.9 \\
\hline Exports & 0.1 & 0.3 & 1.0 & $\ldots$ & 0.8 & 0.4 \\
\hline Other & 0.1 & 0.1 & 0.1 & $\cdots$ & 0.1 & 6.0 \\
\hline Commercial banks & 80.8 & 83.0 & 85.3 & 85.6 & 85.9 & 75.8 \\
\hline Agriculture & 11.1 & 10.8 & 8.4 & $\ldots$ & 5.1 & 4.4 \\
\hline Cattle & 3.0 & 2.5 & 2.9 & $\ldots$ & 3.0 & 1.3 \\
\hline Industry & 7.8 & 7.3 & 6.9 & $\ldots$ & 9.5 & 9.3 \\
\hline Commerce & 35.9 & 41.5 & 48.5 & $\ldots$ & 42.9 & 33.4 \\
\hline Exports & 10.6 & 10.3 & 7.6 & $\ldots$ & 3.6 & 3.0 \\
\hline Other & 12.4 & 10.5 & 11.0 & $\ldots$ & 21.7 & 24.4 \\
\hline
\end{tabular}

Source: Central Bank of Paraguay.

1/ Excluding credit to the private sector from the Central Bank.

2/ Data in this table are not equal to the totals shown in Table 18 because of the use of different accounting exchange rates. 
Table 21. Paraguay: Banking Soundness Indicators $1 / 2 /$

\begin{tabular}{lrrrrrrr}
\hline & 1992 & 1993 & 1994 & 1995 & 1996 & 1997 \\
\hline & (In billions of guaranies) & & & & \\
& $1,483.7$ & $1,996.4$ & $2,802.7$ & $3,651.9$ & $4,596.5$ & $5,166.0$ \\
Credit to private sector & 66.9 & 90.4 & 132.9 & 249.1 & 347.2 & 689.1 \\
$\begin{array}{l}\text { Nonperforming loans } \\
\text { Capital and reserves }\end{array}$ & 300.4 & 428.2 & 633.8 & 755.1 & 936.4 & $1,125.1$ \\
$\begin{array}{l}\text { Reserves against nonperforming loans } \\
\text { Nonperforming loans as percent of } \\
\text { credit to private sector }\end{array}$ & 28.0 & 40.2 & 76.5 & 67.9 & 173.9 & 248.8 \\
$\begin{array}{l}\text { Nonperforming loans as percent of } \\
\text { capital and reserves }\end{array}$ & (In percent) & & & & & \\
$\begin{array}{l}\text { Reserves against nonperforming loans } \\
\text { as percent of nonperforming loans }\end{array}$ & 4.5 & 4.5 & 4.7 & 6.8 & 7.6 & 13.3 \\
\hline
\end{tabular}

Source: Central Bank of Paraguay.

$1 /$ Includes private banks and the National Development Bank.

2/ Data in this table are not equal to the totals shown in Table 18 because of the use of different accounting exchange rates. 
$-47-$

Table 22. Paraguay: Interest Rate Structure

\begin{tabular}{|c|c|c|c|c|c|c|}
\hline & 1992 & 1993 & 1994 & 1995 & 1996 & 1997 \\
\hline \multicolumn{7}{|c|}{ I. Lending Operations } \\
\hline \multicolumn{7}{|l|}{ Commercial banks } \\
\hline Agriculture, industry, and exports & 29.0 & 28.0 & 27.0 & 30.0 & 26.4 & 23.6 \\
\hline Commercial & 30.0 & 32.0 & 33.0 & 31.0 & 27.2 & 25.6 \\
\hline Personal & 31.0 & 35.0 & 37.0 & 30.0 & 35.6 & 31.2 \\
\hline \multicolumn{7}{|l|}{ National Development Bank } \\
\hline Agriculture & 25.0 & 25.0 & 29.0 & 27.0 & 24.5 & 24.3 \\
\hline Development & 25.0 & 25.0 & 29.0 & 27.0 & 24.5 & 24.3 \\
\hline Commercial & 33.0 & 33.0 & 31.0 & 32.0 & 26.0 & 27.1 \\
\hline \multicolumn{7}{|l|}{ Other institutions } \\
\hline Cattle Fund & 27.0 & 27.0 & 27.0 & 28.0 & 30.7 & 24.6 \\
\hline Finance companies & 44.0 & 47.0 & 48.0 & 44.0 & 37.7 & 53.6 \\
\hline \multicolumn{7}{|l|}{$\begin{array}{l}\text { Finance companies } \\
\text { Paraguayan Institute for Housing and }\end{array}$} \\
\hline Urbanization/National Housing Board 3/ & 17.0 & 17.0 & 17.0 & 17.0 & $\ldots$ & $\ldots$ \\
\hline Bank Employees' Pension Fund & 27.0 & 27.0 & 27.0 & 30.0 & 29.0 & 29.1 \\
\hline \multirow[t]{2}{*}{ Technical Execution Program Unit } & $\ldots$ & ... & 26.0 & 22.6 & 18.3 & 16.6 \\
\hline & \multicolumn{6}{|c|}{ II. Deposits and Other Obligations } \\
\hline Central Bank & & & & & & \\
\hline Central Bank's short term paper (LRM) & $\cdots$ & 21.9 & 19.7 & 17.8 & 12.1 & 11.7 \\
\hline \multicolumn{7}{|l|}{ Banks } \\
\hline \multicolumn{7}{|l|}{$\begin{array}{l}\text { Banks } \\
\text { Local currency deposits }\end{array}$} \\
\hline Savings deposits & 10.0 & 11.0 & 11.0 & 10.0 & 9.0 & 7.0 \\
\hline \multicolumn{5}{|l|}{$\begin{array}{l}\text { Savings deposits } \\
\text { Fixed deposits }\end{array}$} & 12.0 & 10.1 \\
\hline 60 days & 17.0 & $\begin{array}{l}18.0 \\
18.0\end{array}$ & 15.0 & 15.0 & 11.9 & 11.1 \\
\hline 61 to 90 days & $\begin{array}{l}17.0 \\
14.0\end{array}$ & $\begin{array}{l}18.0 \\
15.0\end{array}$ & 28.0 & 15.0 & 17.6 & 11.2 \\
\hline 91 to 180 days & $\begin{array}{l}14.0 \\
14.0\end{array}$ & 12.0 & $\ldots$ & 13.0 & 9.0 & 12.0 \\
\hline Over 180 days : & 14.0 & 23.0 & 23.0 & 20.0 & 16.4 & 14.3 \\
\hline Certificates of deposit $4 /$ & 20.0 & 5.0 & 8.0 & 6.0 & 5.9 & $\begin{array}{r}1.2 \\
5.4\end{array}$ \\
\hline Foreign currency deposits & 6.0 & 5.6 & & & & \\
\hline Finance companies & & & & & & \\
\hline Promissory notes & 26.0 & 28.0 & 27.0 & 26.0 & 21.2 & 21.6 \\
\hline Certificates of deposit & 28.0 & 28.0 & 27.0 & 26.0 & 24.4 & 23.1 \\
\hline
\end{tabular}

Source: Central Bank of Paraguay.

1/ Commission rates were applicable one time only.

2/ The Central Bank guarantees 75 percent of these bank loans.

3/ Maximum lending rate permissible is 22 percent, excluding commission. The Paraguayan Institute for Housing and Urbanization was legally abolished in March 1992, with all its assets and liabilities passing to the National Housing Board. 4/ Rates on six-month deposits. 
Table 23. Paraguay: Balance of Payments

\begin{tabular}{|c|c|c|c|c|c|c|c|}
\hline \multicolumn{8}{|c|}{ (In millions of U.S. dollars) } \\
\hline Current account & 86.6 & 245.0 & -55.8 & -363.8 & -317.2 & -482.9 & -264.9 \\
\hline Trade balance & 130.0 & 167.6 & -181.5 & -261.9 & -378.5 & -446.6 & -276.0 \\
\hline Exports & $2,118.0$ & $2,947.2$ & $3,422.0$ & $4,231.2$ & $4,003.7$ & $3,768.0$ & $3,383.7$ \\
\hline Re-exports & $1,342.6$ & $2,104.4$ & $2,512.0$ & $2,994.0$ & $2,672.5$ & $2,378.0$ & $1,861.7$ \\
\hline Exports of domestic products & 775.4 & 842.8 & 910.0 & $1,237.2$ & $1,331.2$ & $1,390.0$ & $1,522.0$ \\
\hline Imports & $-1,988.0$ & $-2,779.6$ & $-3,603.5$ & $-4,493.1$ & $-4,382.2$ & $-4,214.6$ & $-3,659.7$ \\
\hline Imports of re-exported products & -994.5 & $-1,606.6$ & $-1,903.5$ & $-2,283.4$ & $-2,118.3$ & $-1,884.9$ & $-1,259.6$ \\
\hline Domestic market imports & -993.5 & $-1,173.0$ & $-1,700.0$ & $-2,209.7$ & $-2,263.9$ & $-2,329.7$ & $-2,400.1$ \\
\hline Services (net) & -72.0 & -73.3 & -23.8 & -247.1 & -96.8 & -170.3 & -107.3 \\
\hline Transport & -192.2 & -224.8 & -212.6 & -350.8 & -243.3 & -292.3 & -212.1 \\
\hline Travel & 19.2 & 66.4 & 4.4 & -8.4 & 2.9 & -78.7 & -70.0 \\
\hline Other & 101.0 & 85.1 & 184.4 & 112.1 & 143.6 & 200.7 & 174.8 \\
\hline Factor income & -43.6 & 50.4 & 118.0 & 73.0 & 103.2 & 87.4 & 60.5 \\
\hline Transfers & 72.2 & 100.3 & 31.5 & 72.2 & 54.9 & 46.6 & 57.9 \\
\hline Capital account & -98.2 & 189.5 & 286.1 & 523.0 & 190.6 & 572.7 & 165.9 \\
\hline Foreign direct investment & 120.5 & 78.9 & 97.0 & 156.1 & 245.9 & 221.0 & 243.1 \\
\hline Long-term capital (public sector) & -309.1 & 22.8 & 80.5 & 54.2 & 40.1 & 119.1 & 48.6 \\
\hline Disbursements & 103.5 & 130.1 & 146.5 & 220.2 & 164.5 & 214.7 & 169.7 \\
\hline Amortizations & -490.4 & -162.4 & -146.9 & -166.0 & -124.4 & -95.6 & -121.1 \\
\hline Commercial credit & 77.8 & 55.1 & 80.9 & -167.4 & 103.5 & 261.1 & 8.1 \\
\hline Other & 12.6 & 32.7 & 27.7 & 480.1 & -198.9 & -28.5 & -125.8 \\
\hline Errors and Omissions & -352.4 & -347.5 & 116.1 & -96.8 & 82.4 & -306.2 & 0.0 \\
\hline Overall balance & -364.0 & 87.0 & 346.4 & 62.4 & -44.2 & -216.4 & -99.0 \\
\hline \multicolumn{8}{|l|}{ Memorandum items } \\
\hline Current account in percent of GDP & 1.3 & 3.6 & -0.7 & -4.1 & -3.3 & -5.0 & -3.1 \\
\hline External public debt in percent of GDP & 19.4 & 17.7 & 15.8 & 15.6 & 14.5 & 15.0 & 17.3 \\
\hline Debt service in months of exports GNFS & 2.9 & 0.8 & 0.7 & 0.5 & 0.5 & 0.5 & 0.6 \\
\hline Exports of goods, volume growth & & & 9.2 & 34.0 & 9.3 & 9.6 & 6.0 \\
\hline Imports of goods, volume growth & & & 7.2 & 15.5 & 4.0 & 5.5 & 1.0 \\
\hline Reserves in months of imports & & & 3.5 & 3.0 & 2.9 & 2.4 & 2.5 \\
\hline
\end{tabular}

Sources: Central Bank of Paraguay; and Fund staff estimates. 
Table 24. Paraguay: Composition of Registered Exports (f.o.b.)

\begin{tabular}{|c|c|c|c|c|c|c|}
\hline & 1992 & 1993 & $\cdot 1994$ & 1995 & 1996 & 1997 \\
\hline \multicolumn{7}{|c|}{ (In millions of U.S dollars) } \\
\hline Total registered exports & 656.6 & 725.2 & 816.8 & 919.3 & $1,043.4$ & $1,142.8$ \\
\hline Primary products & 442.4 & 500.9 & 521.8 & 602.8 & 647.3 & 698.6 \\
\hline Agricultural products & 354.9 & 397.5 & 402.1 & 481.0 & 551.7 & 600.8 \\
\hline Cotton & 209.4 & 164.9 & 170.9 & 297.2 & 217.7 & 97.1 \\
\hline Coffee & 1.1 & 1.8 & 1.8 & 0.8 & 0.8 & 2.0 \\
\hline Tobacco & 6.9 & 7.0 & 6.9 & 6.8 & 8.8 & 8.0 \\
\hline Yerba mate & 0.3 & 0.1 & 0.2 & 0.2 & 0.1 & 0.2 \\
\hline Soya & 137.2 & 223.7 & 222.3 & 175.9 & 324.2 & 493.6 \\
\hline Livestock & 85.0 & 101.0 & 118.4 & 113.4 & 88.8 & 91.6 \\
\hline Meat & 47.5 & 47.1 & 55.4 & 54.9 & 46.8 & 49.2 \\
\hline Hides & 37.5 & 53.9 & 63.0 & 58.6 & 42.0 & 42.4 \\
\hline Alcohol & 0.0 & 0.1 & 0.8 & 2.5 & 3.1 & 2.3 \\
\hline Sugar & 2.5 & 2.3 & 0.5 & 6.0 & 3.8 & 3.9 \\
\hline Manufactured products & 214.1 & 224.3 & 295.0 & 316.5 & 396.1 & 444.2 \\
\hline Oils & 55.3 & 44.2 & 69.3 & 73.1 & 77.2 & 69.2 \\
\hline Coconut & 2.4 & 0.0 & 3.0 & 0.4 & 2.3 & 1.1 \\
\hline Tung & 6.1 & 4.1 & 4.6 & 4.0 & 3.4 & 7.4 \\
\hline Soya & 32.0 & 32.0 & 51.6 & 57.8 & 58.1 & 48.0 \\
\hline Essences & 14.7 & 8.2 & 10.2 & 10.9 & 13.4 & 12.8 \\
\hline Lumber & 53.3 & 63.8 & 78.6 & 89.3 & 94.0 & 100.7 \\
\hline \multirow[t]{2}{*}{ Other } & 105.5 & 116.3 & 147.1 & 154.1 & 224.9 & 274.3 \\
\hline & \multicolumn{4}{|c|}{ (In percent of total registered exports) } & \multicolumn{2}{|c|}{.. } \\
\hline Total registered exports & 100.0 & 100.0 & 100.0 & 100.0 & 100.0 & 100.0 \\
\hline Primary products & 67.4 & 69.1 & 63.9 & 65.6 & 62.0 & 61.1 \\
\hline Agricultural products & 54.1 & 54.8 & 49.2 & 52.3 & 52.9 & 52.6 \\
\hline Livestock & 12.9 & 13.9 & 14.5 & 12.3 & 8.5 & 8.0 \\
\hline Other & 0.4 & 0.3 & 0.2 & 0.9 & 0.7 & 0.5 \\
\hline Manufactured products & 32.6 & 30.9 & 36.1 & 34.4 & 38.0 & 38.9 \\
\hline Oils & 8.4 & 6.1 & 8.5 & 7.9 & 7.4 & 6.1 \\
\hline Lumber & 8.1 & 8.8 & 9.6 & 9.7 & 9.0 & 8.8 \\
\hline - Other & 16.1 & 16.0 & 18.0 & 16.8 & 21.6 & 24.0 \\
\hline \multicolumn{7}{|l|}{ Memorandum items } \\
\hline International price of soya $1 /$ & 570.4 & 626.7 & 625.7 & 606.0 & 754.9 & 783.1 \\
\hline International price of cotton $2 /$ & 58.2 & 59.9 & 75.5 & 98.4 & 78.2 & 73.3 \\
\hline
\end{tabular}

Source: Central Bank of Paraguay

1/ U.S. cent per bushel, Chicago.

2/U.S. cent per pound, New York. 
Table 25. Paraguay: Composition of Registered Imports (f.o.b.)

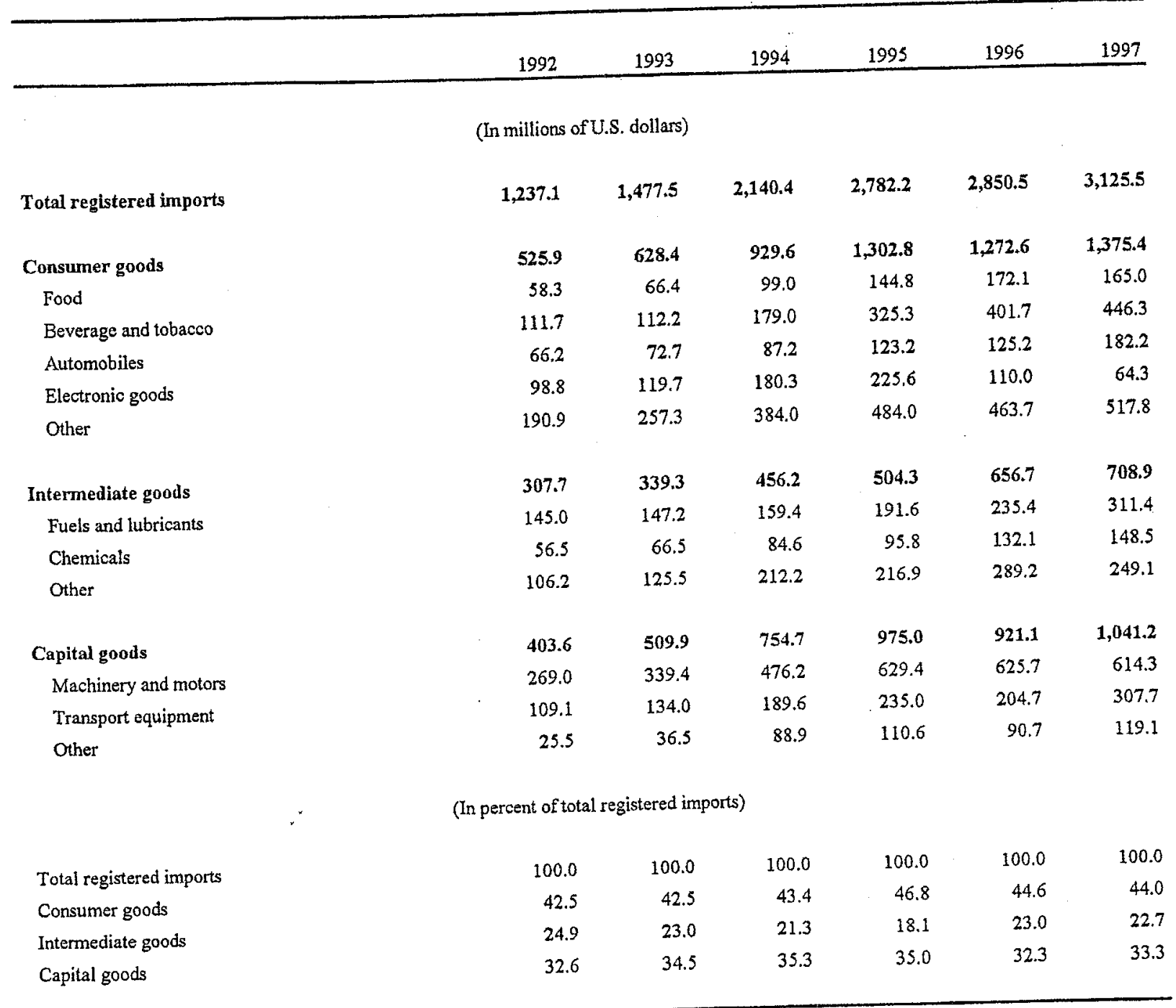

Source: Central Bank of Paraguay. 
Table 26. Paraguay: Direction of Trade Structure

(In percent)

\begin{tabular}{|c|c|c|c|c|c|c|c|c|c|c|c|c|}
\hline & \multicolumn{6}{|c|}{ Exports } & \multicolumn{6}{|c|}{ Imports } \\
\hline & 1992 & 1993 & 1994 & 1995 & 1996 & 1997 & 1992 & 1993 & 1994 & 1995 & 1996 & 1997 \\
\hline Total & 100.0 & 100.0 & 100.0 & 100.0 & 100.0 & 100.0 & 100.0 & 100.0 & 100.0 & 100.0 & 100.0 & 100.0 \\
\hline Western Hemisphere & 55.5 & 59.4 & 65.2 & 65.6 & $\ldots 78.9$ & 74.1 & 67.5 & 71.4 & 69.3 & 68.8 & 71.0 & 72.3 \\
\hline United States & 5.1 & 6.4 & 9.2 & 4.7 & 3.7 & 3.0 & 21.5 & 19.2 & 22.4 & 22.2 & 21.4 & 19.1 \\
\hline Argentina & 8.6 & 8.6 & 7.8 & 10.9 & 14.6 & 21.4 & 14.1 & 13.2 & 14.0 & 14.1 & 13.9 & 14.4 \\
\hline Brazil & 24.9 & 32.5 & 38.5 & 40.0 & 48.8 & 39.1 & 28.2 & 35.3 & 29.7 & 29.1 & 31.6 & 34.2 \\
\hline Chile & 8.1 & 8.0 & 6.1 & 4.5 & 5.6 & 3.7 & 2.1 & 1.8 & 1.6 & 1.7 & 1.6 & 1.7 \\
\hline Unuguay & 1.4 & 0.8 & 0.9 & 1.1 & 2.0 & 1.6 & 0.5 & 0.6 & 0.7 & 0.6 & 1.2 & 1.6 \\
\hline Other & 7.4 & 3.1 & 2.6 & 4.4 & 4.1 & 5.2 & 1.1 & 1.3 & 0.9 & 1.1 & 1.4 & 1.3 \\
\hline Europe & 32.3 & 34.2 & 28.4 & 23.6 & 13.9 & 14.8 & 10.9 & 8.5 & 9.4 & 9.7 & 10.3 & 10.7 \\
\hline Belgium-Luxembourg & 2.6 & 7.0 & 6.5 & 3.4 & 0.7 & 0.4 & 0.2 & 0.2 & 0.2 & 0.2 & 0.2 & 0.2 \\
\hline France & 4.5 & 2.2 & 2.0 & 1.6 & 1.4 & 0.8 & 1.3 & 1.0 & 1.3 & 0.9 & 0.9 & 1.1 \\
\hline Germany & 3.7 & 3.9 & 3.0 & 7.4 & 1.6 & 1.0 & 2.3 & 2.2 & 2.4 & 2.3 & 2.6 & 2.1 \\
\hline Greece & 0.2 & 0.0 & 0.0 & 0.0 & 0.0 & 0.0 & 0.0 & 0.0 & 0.0 & 0.0 & 0.0 & 0.0 \\
\hline Italy & 7.3 & 5.9 & 3.5 & 3.1 & 2.8 & 2.0 & 1.7 & 1.1 & 1.3 & 1.7 & 2.5 & 2.1 \\
\hline Netherlands & 4.4 & 3.8 & 5.7 & 3.4 & 3.5 & 8.2 & 0.4 & 0.6 & 0.5 & 0.4 & 0.4 & 0.3 \\
\hline Portugal & 4.4 & 0.5 & 1.6 & 1.2 & 1.3 & 0.1 & 0.0 & 0.0 & 0.1 & 0.0 & 0.0 & 0.1 \\
\hline Spain & 3.4 & 9.8 & 4.0 & 2.5 & 1.9 & 1.6 & 0.5 & 0.5 & 0.3 & 0.7 & 0.8 & 1.1 \\
\hline Switzerland & 0.5 & 0.2 & 0.4 & 0.3 & 0.2 & 0.1 & 0.7 & 0.5 & 0.7 & 0.6 & 0.6 & 0.3 \\
\hline United Kingdom & 0.6 & 0.6 & 0.6 & 0.4 & 0.4 & 0.5 & 3.2 & 2.0 & 2.1 & 2.4 & 2.1 & 2.7 \\
\hline Other & 0.6 & 0.3 & 1.2 & 0.4 & 0.1 & 0.1 & 0.7 & 0.5 & 0.5 & 0.5 & 0.3 & 0.7 \\
\hline Asia & 10.9 & 6.0 & 5.0 & 10.0 & 6.5 & 10.7 & 20.1 & 18.2 & 20.1 & 21.0 & 18.2 & 16.3 \\
\hline Hong Kong & 0.3 & 0.1 & 0.2 & 0.5 & 0.2 & 0.5 & 6.3 & 6.5 & 8.7 & 9.4 & 7.3 & 5.7 \\
\hline Japan & 2.3 & 4.4 & 3.3 & 2.9 & 3.1 & 7.0 & 7.6 & 7.1 & 4.8 & 4.6 & 2.3 & 4.5 \\
\hline Other & 8.3 & 1.6 & 1.5 & 6.6 & 3.1 & 3.2 & 6.2 & 4.6 & 6.5 & 7.0 & 8.5 & 6.1 \\
\hline Africa & 1.2 & 0.4 & 0.5 & 0.5 & 0.5 & 0.2 & 1.4 & 1.9 & 1.2 & 0.5 & 0.4 & 0.4 \\
\hline Algeria & 0.0 & 0.0 & 0.0 & 0.0 & 0.0 & 0.1 & 1.2 & 1.7 & 0.8 & 0.4 & 0.2 & 0.1 \\
\hline Other & 1.2 & 0.4 & 0.5 & 0.5 & 0.5 & 0.1 & 0.2 & 0.1 & 0.4 & 0.2 & 0.2 & 0.3 \\
\hline Other & 0.1 & 0.0 & 0.8 & 0.3 & 0.2 & 0.2 & 0.1 & 0.1 & 0.1 & 0.1 & 0.1 & 0.3 \\
\hline
\end{tabular}

Source: Direction of Trade Statistics, MMF. 
Table 27. Paraguay: International Reserves of the Banking System

(In millions of U.S. dollars)

\begin{tabular}{|c|c|c|c|c|c|c|}
\hline & 1992 & 1993 & 1994 & 1995 & 1996 & 1997 \\
\hline Total net reserves & 807 & 916 & 1,221 & 1,164 & 1,237 & 925 \\
\hline Central Bank & 611 & 698 & 1,044 & 1,106 & 1,062 & 846 \\
\hline Assets & 611 & 698 & 1,044 & 1,106 & 1,062 & 846 \\
\hline Gold & 12 & 14 & 13 & 14 & 13 & 10 \\
\hline IMF reserve position & 23 & 23 & 21 & 22 & 19 & 20 \\
\hline SDRs & 85 & 89 & 99 & 107 & 105 & 103 \\
\hline U.S. dollars & 330 & 416 & 569 & 595 & 415 & 381 \\
\hline Other currencies & 123 & 102 & 327 & 378 & 327 & 192 \\
\hline ALADI float (net) & 38 & 15 & 15 & -9 & 40 & 1 \\
\hline Other & 0 & 39 & 0 & 0 & 142 & 140 \\
\hline Liabilities & 0 & 0 & 0 & 0 & 0 & 0 \\
\hline Use of Fund resources & 0 & 0 & 0 & 0 & 0 & 0 \\
\hline Other & 0 & 0 & 0 & 0 & 0 & 0 \\
\hline Commercial banks 1 / & 196 & 219 & 177 & 27 & 175 & 79 \\
\hline Assets & 240 & 300 & 302 & 416 & 338 & 293 \\
\hline Liabilities & 44 & 81 & 125 & 389 & 163 & 214 \\
\hline \multicolumn{7}{|l|}{ Memorandum items } \\
\hline $\begin{array}{l}\text { Valuation change on } \\
\text { central bank reserves }\end{array}$ & -13 & 1 & 33 & 21 & -50 & 0 \\
\hline $\begin{array}{l}\text { International reserves in months of } \\
\text { imports of goods and nonfactor } s\end{array}$ & 2.9 & 2.5 & 3.0 & 2.5 & -2.5 & 2.0 \\
\hline
\end{tabular}

Sources: Central Bank of Paraguay; and Fund staff estimates.

1/ Includes the National Development Bank. 
Table 28. Paraguay: Outstanding Medium- and Long-Term External Public Debt

(In millions of U.S. dollars)

\begin{tabular}{|c|c|c|c|c|c|c|}
\hline & 1992 & 1993 & 1994 & 1995 & 1996 & 1997 \\
\hline $\begin{array}{l}\text { Public sector and officially guaranteed } \\
\text { debt outstanding at end of period } 1 /\end{array}$ & 1,249 & 1,217 & 1,241 & 1,405 & 1,398 & 1,443 \\
\hline \multicolumn{7}{|l|}{ By debtor: } \\
\hline Central Administration & 529 & 530 & 568 & 906 & 935 & 987 \\
\hline Public enterprises & 482 & 461 & 471 & 428 & 392 & 388 \\
\hline Rest of public sector & 237 & 226 & 202 & 71 & 71 & 68 \\
\hline \multicolumn{7}{|l|}{ By creditor: } \\
\hline International organizations & 633 & 627 & 612 & 760 & 814 & 903 \\
\hline IBRD & 181 & 150 & 121 & 149 & 152 & 173 \\
\hline $\mathrm{IDB}$ & 403 & 429 & 446 & 554 & 590 & 650 \\
\hline Other & 49 & 48 & 45 & 57 & 72 & 80 \\
\hline Official bilateral creditors & 590 & 567 & 603 & 625 & 563 & 523 \\
\hline Brazil & 0 & 0 & 0 & 0 & 0 & 0 \\
\hline France & 91 & 63 & 59 & 40 & 36 & 26 \\
\hline Germany & 152 & 135 & 138 & 131 & 99 & 90 \\
\hline Japan & 214 & 260 & 323 & 347 & 319 & 297 \\
\hline Other & 133 & 109 & 83 & 107 & 109 & 110 \\
\hline Commercial banks and other creditor & 26 & 24 & 25 & 22 & 21 & 17 \\
\hline Debt service payments & 629 & 233 & 222 & 208 & 188 & 169 \\
\hline \multicolumn{7}{|l|}{ Memorandum items } \\
\hline Public debt in percent of GDP & 19.5 & 17.8 & 15.8 & 15.7 & 14.5 & 15.0 \\
\hline Debt service ratio $2 /$ & 24.4 & 6.7 & 5.7 & 4.4 & 4.1 & 3.9 \\
\hline
\end{tabular}

Sources: Central Bank of Paraguay; and Fund staff estimates.

1/ Includes outstanding arrears.

2/ In relation to exports of goods and nonfactor services. 